\title{
THE MISLEADING NATURE OF PUBLIC FORUM ANALYSIS: CONTENT AND CONTEXT IN FIRST AMENDMENT ADJUDICATION*
}

\section{Daniel A. Farber** and John E. Nowak***}

$\mathrm{M}$ ANY of the Burger Court's first amendment decisions focus on the scope of governmental power to regulate speech based upon its content. ${ }^{1}$ The Court has had little trouble with traditional content regulation cases that involve outright proscription of certain types of speech. ${ }^{2}$ Similarly, it has had httle trouble with traditional time, place, or manner regulations, which relate only to the physical context of speech and do not involve content regulation at all. ${ }^{3}$ The Court has had a great deal of difficulty, however, with hybrid regulations involving governmental limitations on speech in a specific context. Such hybrid regulations relate to content, but they are limited to certain locations, media, or speakers. ${ }^{4}$ Although the government may be pursuing some goal unrelated to the proscription of a message, these hybrid regulations often directly impair some people's ability to communicate a message in a certain

* Copyrigbt $\odot 1984$ by Daniel A. Farber and John E. Nowak.

** Professor of Law, University of Minnesota.

*** Professor of Law, University of Illinois.

1 See, e.g., Minnesota State Bd. for Community Colleges v. Knight, 104 S. Ct. 1058 (1984); Perry Educ. Ass'n v. Perry Local Educators' Ass'n, 460 U.S. 37 (1983); Widmar v. Vincent, 454 U.S. 263 (1981); Young v. American Mini Theatres, Inc., 427 U.S. 50 (1976). "Contentbased" regulations can restrict speech either on the basis of its subject matter (no discussion of the Vietnam war) or on the basis of its viewpoint (no criticism of American involvement in Vietnam).

2 See, e.g., Bolger v. Youngs Drug Prods. Corp., 103 S. Ct. 2875 (1983); New York v. Ferber, 458 U.S. 747 (1982); Miller v. California, 413 U.S. 15 (1973); Cohen v. California, 403 U.S. 15 (1971).

s See, e.g., United States v. Grace, 461 U.S. 171 (1983); Heffron v. International Soc'y for Krishna Consciousness, Inc., 452 U.S. 640 (1981).

- See, e.g., Board of Educ. v. Pico, 457 U.S. 853 (1982) (school board removal of books from school hibraries); FCC v. Pacifica Found., 438 U.S. 726 (1978) ("indecent" language regulated in radio broadcasts); Young v. American Mini Theatres, Inc., 427 U.S. 50 (1976) ("adult" entertainment subject to special zoning regulation). For a criticism of the Court's efforts in this area, see Stone, Restrictions of Speech Because of its Content: The Peculiar Case of Subject-Matter Restrictions, 46 U. Chi. L. Rev. 81, 83-100 (1978). 
way. ${ }^{5}$ Similar problems are posed when the government withholds support for the communication because of the content of the message or the identity of the speaker. ${ }^{\circ}$

The Court has experimented with several approaches to these hybrid regulations. In the early 1970's, it began to espouse the view that the first amendment almost completely prohibited governmental regulation of speech based on content. ${ }^{7}$ Despite the language of some opinions, this approach probably never actually determined the outcome of any cases. ${ }^{8}$ In any event, as time went on, the Court recognized more and more exceptions to this "rule" of content neutrality. ${ }^{\circ}$ In an attempt to regain some doctrinal coherence, the Justices in recent years have focused on the issue of whether speech is communicated in a public forum..$^{10}$ Public forum analysis might well be called the "geographical" approach to first amendinent law, because results often hinge almost entirely on the speaker's location.

The Court recently set out this geographical approach at some length in Perry Education Association v. Perry Local Educators' Association. ${ }^{11}$ Perry distinguishes three kinds of forums in which communication takes place. In a classic, or quintessential, public forum, such as a park or a sidewalk, the Court strictly scrutinizes a content-based regulation to see whether it is narrowly drawn to serve a compelling governmental interest. The Court also requires

s See, e.g., FCC v. Pacifica Found., 438 U.S. 726 (1978); Pickering v. Board of Educ., 391 U.S. 563 (1968). Similar problems are presented when the limitation on speech is keyed to the identify of the speaker rather than the medium of communication. See J. Nowak, R. Rotunda \& J. Young, Constitutional Law 1001-03 (2d ed. 1983) (discussing regulation of government employees' pohtical activities).

- See, e.g., Minnesota State Bd. for Community Colleges v. Knight, 104 S. Ct. 1058 (1984) (nonunion teachers excluded from school policy discussions); Perry Educ. Ass'n v. Perry Local Educators' Ass'n, 460 U.S. 37 (1983) (nonunion teachers denied access to school mail systein).

' See Police Dep't v. Mosley, 408 U.S. 92 (1972).

- See Farber, Content Regulation and the First Amendment: A Revisionist View, 68 Geo. L.J. 727, 727-31 (1980); Stephan, The First Amendment and Content Discrimination, 68 Va. L. Rev. 203, 205-06, 236 (1982).

- See Note, Content Regulation and the Dimensions of Free Expression, 96 Harv. L. Rev. 1854 (1983); id. at 1856 n.15.

10 This "geographical" analysis of the first amendment has been used in several recent cases, such as United States v. Grace, 461 U.S. 171 (1983), and United States Postal Serv. v. Council of Greenburgh Civic Ass'ns, 453 U.S. 114 (1981).

11460 U.S. 37 (1983). The test discussed in the text is found in id. at 45-46. For further discussion of Perry, see infra text accompanying notes 167-82. 
a compelling interest to justify any blanket prohibition of all speech. When the forum is not a historic type of public forum, but has nonetheless been opened to the pubhic's first amendment activities, the Court again strictly scrutinizes content regulation, but allows the government to close the forum entirely. Finally, in a nonpublic forum, the government is free to exclude speech or speakers based upon the content of the message, except in cases of viewpoint discrimination. ${ }^{12}$

Public forum analysis appears to be increasing in importance. The doctrine traces back to a famous dictum of Justice Roberts ${ }^{13}$ and received further attention from Professor Kalven almost twenty years ago, ${ }^{14}$ but it was almost never used in Supreme Court opinions until recently. The phrase "public forum" has appeared in only thirty-two Supreme Court decisions. ${ }^{15}$ Only two of these

\footnotetext{
12 Note that the mere fact that government owned or operated property is open to members of the public, who are free to come and go at will, does not make it a public forum. See United States v. Grace, 461 U.S. 171, 177 (1983). For a discussion of the origins of the Perry approach, see Stone, Fora Americana: Speech in Public Places, 1974 Sup. Ct. Rev. 233.

${ }^{13}$ See Hague v. Committee for Indus. Org., 307 U.S. 496 (1939). Justice Roberts argued that parks and streets are public fora whose use "may be regulated in the interest of all . . . but . . . must not, in the guise of regulation, be abridged or demed." Id. at 515-16.

14 See Kalven, The Concept of the Public Forum: Cox v. Louisiana, 1965 Sup. Ct. Rev. 1.

15 This assertion is made on the basis of LEXIS and WESTLAW" searclies" of Supreme Court opinions since 1925. The computer search of the cases yielded the following citations: Clark v. Community for Creative Non-Violence, $104 \mathrm{~S}$. Ct. 3065 (1984); Members of the City Council of Los Angeles v. Taxpayers for Vincent, $104 \mathrm{~S}$. Ct. 2118 (1984); Minnesota State Bd. for Community Colleges v. Knight, 104 S. Ct. 1058 (1984); Bolger v. Young Drug Prods. Corp., 103 S. Ct. 2875 (1983); United States v. Grace, 461 U.S. 171 (1983); Connick v. Myers, 461 U.S. 138 (1983); Perry Educ. Ass'n v. Perry Local Educators' Ass'n, 460 U.S. 37 (1983); Dallas County Hosp. Dist. v. Dallas Ass'n of Community Orgs. for Reform Now, 459 U.S. 1052 (1982); Widmar v. Vincent, 454 U.S. 263 (1981); United States Postal Serv. v. Council of Greenburgh Civic Ass'ns, 453 U.S. 114 (1981); Heffron v. International Soc'y for Krishna Consciousness, Inc., 452 U.S. 640 (1981); Carey v. Brown, 447 U.S. 455 (1980); Consolidated Edison Co. v. Public Serv. Comm'n, 447 U.S. 530 (1980); PruneYard Shopping Center v. Robins, 447 U.S. 74 (1980); Wolston v. Reader's Digest Ass'n, 443 U.S. 157 (1979); Jones v. North Carolina Prisoners' Labor Union, Inc., 433 U.S. 119 (1977); City of Madison Joint School Dist. v. Wisconsin Employment Relations Comm'n, 429 U.S. 167 (1976); Young v. American Mini Theatres, Inc., 427 U.S. 50 (1976); Greer v. Spock, 424 U.S. 828 (1976); Hudgens v. NLRB, 424 U.S. 507 (1976); Time, Inc. v. Firestone, 424 U.S. 448 (1976); Erznoznik v. City of Jacksonville, 422 U.S. 205 (1975); Southeastern Promotions, Ltd. v. Conrad, 420 U.S. 546 (1975); American Radio Ass'n v. Mobile S.S. Ass'n, 419 U.S. 215 (1974); Lehman v. City of Sliaker Heights, 418 U.S. 298 (1974); Spence v. Washington, 418 U.S. 405 (1974); CBS v. Democratic Nat'l Comm., 412 U.S. 94 (1973); Police Dep't v. Mosley, 408 U.S. 92 (1972); Grayned v. City of Rockford, 408 U.S. 104 (1972); Lloyd Corp. v. Tanner, 407 U.S. 551 (1972); Griffin v. California, 380 U.S. 609 (1965); International Ass'n of Machinists v. Street, 367 U.S. 740 (1961).
} 
decisions were rendered prior to 1970 and thirteen of the thirtytwo have been in the 1980's.

The pubhic forum problem is more longstanding and more significant than a listing of thirty-two cases would indicate. The crux of the problem is the government's power to differentiate among speakers or types of speech based on their impact on a particular environment. Notwithstanding the arguments made for content neutrality in some judicial opinions ${ }^{16}$ and scholarly analyses, ${ }^{17}$ it is clear today that content regulation is not absolutely impermissible. Nor is governmental regulatory power limited to the categories of speech that lie wholly outside the protection of the first amendment. Yet the Court has been unable to articulate any he between permissible content regulation and censorship. ${ }^{18}$ The Court's inability to adopt a framework for analyzing such problems, exacerbated by its reliance on public forum analysis, has produced fragmented Courts and incoherent opinions in cases such as Young $v$. American Mini Theatres, Inc., ${ }^{19}$ FCC v. Pacifica Foundation, ${ }^{20}$

${ }^{16}$ See, e.g., Young v. American Mini Theatres, Inc., 427 U.S. 50, $84-85$ (1976) (Stewart, J., dissenting); Pohice Dep't v. Mosley, 408 U.S. 92, 95-96, 99 (1972).

${ }^{17}$ See, e.g., Ely, Flag Desecration: A Case Study in the Roles of Categorization and Balancing in First Amendment Analysis, 88 Harv. L. Rev. 1482 (1975); Karst, Equality as a Central Principle in the First Amendment, 43 U. Chi. L. Rev, 20, 28-35 (1975).

18 See, Stone, Content Regulation and the First Amendment, 25 Wm. \& Mary L. Rev. 189, 240-42 (1983) (Court's treatment of subject matter restrictions is inconsistent). For critiques of the Court's opinions in this area, see Farber, supra note 8; Stephan, supra note 8, at 227-31.

Professor Redish has noted that the Supreme Court's inability to establish a coherent "overbreadth doctrine" stems froin the defects of its content-neutrality doctrine. Redish, The Warren Court, the Burger Court and the First Amendment Overbreadth Doctrine, 78 Nw. U.L. Rev. 1031 (1983).

19427 U.S. 50 (1976). Young involved zoning ordinances that prohibited location of an "adult movie theater," defined as one presenting certain specified "sexual activities" or "anatomical areas," within 1000 feet of any two other "regulated uses." The ordinances were upheld in a plurality opinion by Justice Stevens on the ground that they were appropriately definite, constituted a valid use of the city's zoning power to regulate the location of commercial establishments, and did not violate equal protection. The rationale was that such communication is entitled to a lesser degree of protection than other forms of expression, id. at 61 , and that the city's interest in the character of its neighborhoods supported the classification made by the ordinances. Id. at 71.

20438 U.S. 726 (1978) (upholding FCC findings that broadcast of a comedic monologue was "indecent" and validly subject to FCC regulation). 
Metromedia, Inc. v. City of San Diego, ${ }^{21}$ and Board of Education v. Pico. ${ }^{22}$

Even when public forum analysis is irrelevant to the outcome of a case, the judicial focus on the pubhic forum concept confuses the development of first amendment principles. For example, in United States Postal Service v. Council of Greenburgh Civic Associations, ${ }^{23}$ the issue was whether nonprofit organizations could be prosecuted for placing pamphlets and messages in the letter boxes of private homes. Although the issue was irrelevant to the decision, in both the majority and three of the four separate opinions much ink was spilled on the subject of whether a letter box was a "public forum." $\mathrm{A}$ letter box miglit be regarded as a public forum because it is a traditional means for the public communication of stamped letters, or as a nonpublic forum because the government has reserved it for the dehvery of stamped mail. The issue in Greenburgh, however, was whetler tlie limitation of public access to this medium of communication so inhibited the communication of ideas as to be inconsistent witl the first amendment. Public forum analysis only clouded consideration of the compatibility of the governmental regulation witl first amendment values. In otler cases, public forum analysis has led tlie Court to a series of seemingly inexplicable distinctions between permissible and impermissible control of speech. Perhaps there is a defensible distinction between leafletting on the steps of the Supreme Court and on the adjoining sidewalk, ${ }^{25}$ or between an educational institution's restrictions on access to unused classrooms and to faculty mailboxes, ${ }^{28}$ but the distinctions are more subtle than public forum analysis would indicate. In a recent case, the Court approved legislation that excluded nonunion professors from discussions with educational administrators relating to issues outside tlie scope of contract bargaming. The Court seemed so comfortable with public

21453 U.S. 490 (1981) (plurality opinion upholding zoning ordinance that prohibited erection of outdoor advertising displays insofar as it regulated commercial speech, but holding facially invalid the same ordinance's ban on noncommercial on-site advertising displays).

2s 457 U.S. 853 (1982). See infra text accompanying notes 144-64.

21453 U.S. 114 (1981).

3 Id. at 128 (Rehnquist, J.); id. at 136 (Brennan, J., concurring); id. at 147 (Marshall, J., dissenting); id. at 152 (Stevens, J., dissenting).

1s The distinction is made in United States v. Grace, 461 U.S. 171, 178-84 (1983).

16 Compare Widınar v. Vincent, 454 U.S. 263 (1981), with Perry Educ. Ass'n v. Perry Local Educators' Ass'n, 460 U.S. 37 (1983). 
forum terminology that it gave virtually no consideration to the first amendment values implicated by governmental restrictions on the ability to present competing views to government decisionmakers. ${ }^{27}$

Our objection to public forum analysis is not that it invariably yields wrong results (although it sometimes does), but that it distracts attention from the first amendment values at stake in a given case. It almost certainly will hinder lower court judges from focusing on those values or from making sense of Supreme Court precedent. ${ }^{28}$ Classifying a medium of communication as a pubhic forum may cause legitimate governmental interests to be thoughtlessly brushed aside; classifying it as something other than a pubhic forum may lead courts to ignore the incompatibility of the challenged regulations with first amendment values.

Our thesis is that there are not three types of pubhic forums, but rather three basic types of first amendment problems. Each type of problem should be addressed in a manner that openly evaluates the particular nature of the threat to first amendment values.

The most basic first amendment problem involves complete prohibition of a message or a category of speech. ${ }^{28}$ Such prohibitions pose the ultimate danger to first amendment values by totally eradicating both the societal and libertarian values underlying the first amendment. ${ }^{30}$ Despite its excessive extension into other areas,

27 See Minnesota State Bd. for Community Colleges v. Knight, 104 S. Ct. 1058 (1984). For a discussion of Knight, see infra text accompanying notes 183-202.

${ }^{28}$ On the importance of guiding lower federal courts (an often-overlooked consideration), see Schauer, "Private" Speech and the "Private" Forum: Givhan v. Western Line School District, 1979 Sup. Ct. Rev. 217, 217-18.

20 See, e.g., Brandenburg v. Ohio, 395 U.S. 444 (1969) (holding unconstitutional the Ohio Syndicalism Act, which purported to punish "mere advocacy"); Yates v. United States, 354 U.S. 298 (1957) (interpreting Smith Act to prohibit only advocacy of direct, forcible overthrow of government); Dennis v. United States, 341 U.S. 494 (1951) (upholding convictions under the Smith Act of Communist Party leaders who advocated forcible overthrow of government); Abrams v. United States, 250 U.S. 616 (1919) (upholding convictions for conspiracy to violate the Espionage Act by calling for a general strike during World War I).

so The societal value of the first amendment is that it provides for an informed citizenry to make decisions affecting society; the libertarian value is that the individual is left free to develop his ideas and to express himself. These complementary values may be different ways of describing the basic role of the first amendment in protecting freedom in society. See F. Schauer, Free Speeclı: A Philosophical Enquiry 3-73 (1982); Perry, Freedom of Expression: An Essay on Theory and Doctrine, 78 Nw. U.L Rev. 1137 (1983); Schauer, Must Speech Be Special?, 78 Nw. U.L. Rev. 1284 (1983); Stone, supra note 4, at 101-07. For further explanation of tlese values, see L. Tribe, American Constitutional Law § 12-1 (1978); 
here the content neutrality doctrine merely restates the first amendment's fundamental prohibition against censorship. ${ }^{31}$

A second kind of problem is posed by content neutral regulations of the time, place, or manner of speech. Such regulations pose a lesser threat to first amendment values but still require independent judicial scrutiny to ensure that speech is not unduly restricted. ${ }^{32}$

The third kind of problem involves what we will call hybrid regulations or situational restraints. These regulations are not content neutral, but they apply only to particular speakers or in particular physical contexts. The government in such cases does not claim the right to suppress some form of speech completely, but argues instead that the speech has a distinctive impact on a particular physical or social environment. Because most individuals are unaffected and most physical environments remain open, the threat to first amendment values is less than that presented by complete censorship. ${ }^{33}$ There is, nevertheless, a significant likelihood that the government, despite its protestations to the contrary, is either deliberately or negligently distorting the "marketplace of ideas" in favor of a particular viewpoint. A standard of review more demanding than that employed when judging content neutral regulations is needed to ensure that situational restraints do not become the functional equivalent of censorship. ${ }^{34} \mathrm{We}$ will call this intermediate standard of review "focused balancing."

Shiffrin, The First Amendment and Economic Regulation: Away from a General Theory of the First Amendment, 78 Nw. U.L. Rev. 1212 (1983); Note, supra note 9, at 1861-67.

Professor Bollinger recently has analyzed and explained how these traditional ways of stating first amendment values may obscure the rule of the first annendment freedoms in the development of "intellectual values." Bollinger, Free Speech and Intellectual Values, 92 Yale L.J. 438 (1983).

${ }^{31}$ See L. Tribe, supra note $30, \S 12-2$, at 580-81; Stephan, supra note 8 , at 233-36 (discussing viewpoint neutrality); Schauer, Categories and the First Amendment: A Play in Three Acts, 34 Vand. L. Rev. 265, 283-89 (1981) (comparing viewpoint and subject matter neutrality).

${ }^{32}$ See L. Tribe, supra note $30, \S 12-2$, at $580-82$; id. $\$ 12-20$, at $682-84$; Stone, supra note 18 , at $190-93$.

${ }^{32}$ See Stone, supra note 4, at 108; Stene, supra note 18, at 200; Farber, supra note 8, at 736-36, 745-46 (defining censorship as governmental hostility to the ideas or information suppressed).

as It is not difficult to imagine the government banning a message it dislikes by finding some distinct reason why that message is inappropriate in every possible situation. At the very least, this strategy would make it possible to relegate that message to a less effective form of communication. 
In Part I of this article, we trace the development of the public forum concept and its relationship to the content neutrality principle. Historically, both ideas have worked well in connection with time, place, and manner restrictions and society-wide censorship. Both have repeatedly broken down, however, when apphied to the hybrid regulations of speech we have termed situational restraints. $^{35}$ In Part II we explain our proposed three-tiered approach to first amendment adjudication, with particular attention to a "focused balancing" test for situational restraints. Part III applies the focused balancing approach to regulations of speech in the context of school governance. ${ }^{36}$ Part IV offers some concluding observations regarding the dangers presented by the Court's rehance on public forum analysis and emphasizes the need for a focused balancing test to protect first amendment values.

\section{The Genesis and Nature of the Public Forum Confusion}

The Burger Court's confusing use of public forum language in recent years can be understood, though not forgiven, in terms of the development of first amendment law in earlier decades. In those decades the Court developed separate approaches to pure content proscription and time, place, and manner regulations. It was also then that the Court first overlooked the distinctive nature of situational regulations and instead attempted to fit all its decisions into either the censorship or the time, place, and manner models. Both models have broken down in cases involving situational regulations.

\section{A. Evolution of the Categorical Approach}

As mentioned earlier, today the Court has settled on a "categorical" approach to broad content proscription problems. ${ }^{37}$ This approach, though, developed slowly during almost a half-century of Supreme Court decisions. In the national security cases that dominated first amendment law before 1960, the Court was unable to

\footnotetext{
ss On the breakdown of the content proscription approach, see infra text accompanying notes 49-53. For the breakdown of the time, place, and manner approach, see infra text accompanying notes 70-78.

so See infra text accompanying notes 124-202.

${ }^{37}$ See sources cited supra notes $30-31$.
} 
define a category of punishable speech. ${ }^{38}$ The "clear and present danger" test was an attempt to define a type of speech that could be legitimately excised from society. The attempt was doomed to failure, however, because the Court did not distinguish between true proscription-the attempt to eliminate an idea such as communism-and situational restraints, such as the famous hypothetical prohibition of yelling "Fire!" in a crowded theater ${ }^{39}$ Failure to distinguish situational regulations from censorship allowed a test best suited for the former to justify the latter. The clear and present danger test degenerated into a rationalization for suppressing dangerous ideas. By the 1960's the Justices differed considerably both in their rhetoric and in the results they reached in particular cases, but very little in the essentials of their analysis. In particular, they agreed on the need for an independent judicial determination of which categories of speech were punishable. ${ }^{40}$ No one, with the possible exception of Justice Douglas in his last years, believed that all speech was absolutely protected. ${ }^{41}$

After Justice Frankfurter retired, none of the Justices advocated his combination of ad hoc balancing and great deference to the legislature's judgement as to the dangerousness of the prohibited speech. The debate in the 1960's was over the definition of the categories of punishable speech, particularly in national security cases. Justice Harlan's majority opinion in Cohen $v$. California ${ }^{42}$ effectively buried the ad hoc balancing approach by explaining the need to define precisely the categories of speech that the government could proscribe. Supreme Court Justices, in Harlan's view, might weigh competing values in defining these categories, but proscription of messages could not be upheld on an ad hoc basis. ${ }^{43}$

\footnotetext{
ss See, e.g., Yates v. United States, 354 U.S. 298 (1957); Dennis v. United States, 341 U.S. 494 (1951); Abrams v. United States, 250 U.S. 616 (1919).

so Schenck v. United States, 249 U.S. 47, 52 (1919) ("The most stringent protection of free speech would not protect a man in falsely sbouting fire in a tbeatre and causing a panic.").

to See, e.g., Cohen v. California, 403 U.S. 15, 24 (1971); Street v. New York, 394 U.S. 576, 591 (1969) (by implication); Scales v. United States, 367 U.S. 203, 230 (1961); Feiner v. New York, 340 U.S. 315, 321 (1951).

12 See Gertz v. Robert Welch, Inc., 418 U.S. 323, 356 (1974) (Douglas, J., dissenting); Paris Adult Theatre I v. Slaton, 413 U.S. 49, $70-73$ (1973) (Douglas, J., dissenting); New York Times Co. v. United States, 403 U.S. 713, 720 (1971) (Douglas, J., concurring).

12403 U.S. 15 (1971) (reversing conviction for breach of peace based upon defendant's appearance in a courthouse with a jacket bearing tbe words "Fuck the Draft").

's In Cohen, Justice Harlan listed the categories of speech that the Supreme Court in
} 
The following decade established that the government had no general authority to proscribe speech simply because the content of that speech interfered with societal or governmental goals. Rather, the government could proscribe only speech falling into certain precise categories, which, briefly summarized, included: (1) speech that created a clear and present danger of illegal behavior, particularly physical violence; ${ }^{44}$ (2) obscenity;"4 (3) defamation; ${ }^{46}$ (4) false or misleading commercial speech; ${ }^{47}$ and (5) child pornog-

earlier cases had found to be punishable and stated:

[W] cannot overempliasize that, in our judgement, most situations where the State has a justifiable interest in regulating speech will fall within one or more of the various established exceptions, discussed above but not applicable liere, to the usual rule that governmental bodies may not prescribe the form or content of individual expression.

Id. at 24.

In another case, decided the same day as Cohen, Justice Harlan noted the difference between ad hoc balancing and definitional halancing:

Once the evident need to balance the values underlying eacls is perceived, it might seem, purely as an abstract matter, that the most utilitarian approach would be to scrutinize carefully every jury verdict in every libel case, in order to ascertain whether the final judgment leaves fully protected whatever First Amendment values transcend the legitimate state interest in protecting the particular plaimtiff who prevailed. This seems to be what is done in the plurality opinion. . . At least where we can discern generally applicable rules that sliould balance with fair precision the competing interests at stake, suclı rules should he preferred to the plurality's approacls both in order to preserve a measure of order and predictability in the law that must govern the daily conduct of affairs and to avoid subjecting the press to judicial second-guessing of the newsworthiness of eacl item they print.

Rosenbloom v. Metromedia, Inc., 403 U.S. 29, 63 (1971) (Harlan, J., dissenting) (footnote omitted).

"See Cohen, 403 U.S. at 20 (words "inherently likely to provoke violent reaction") (citing Chaplinsky v. New Hampshire, 315 U.S. 568, 573 (1942)); Brandenburg v. Ohio, 395 U.S. 444, 447 (1969) (words directed towards inciting imminent lawless action, and likely to lave such effect); see also Gooding v. Wilson, 405 U.S. 518, 523 (1972) ("offensive, derisive, or annoying" words subsequently narrowed by judicial coustruction to "fighting" words). Although one might create separate categories for tlie "fighting words" or "hostile audience" restrictions, we include within the same category all speech that creates a clear danger of a violent reaction to the speaker. For examples of these latter two types of restrictions, see Feiner v. New York, 340 U.S. 315, 320-21 (1951) (hostile audience); Chaplinsky v. New Hampshire, 315 U.S. 568, 573 (1942) (figliting words).

t5 See Miller v. California, 413 U.S. 15, 23 (1973); Paris Adult Theatre I v. Slaton, 413 U.S. 49, 54 (1973).

1s See New York Times Co. v. Sullivan, 376 U.S. 254 (1964); Gertz v. Robert Welch, Inc., 418 U.S. 323 (1974).

47 See Central Hudson Gas \& Elec. Corp. v. Public Serv. Comm'n, 447 U.S 557, 563-66 (1980). 
raphy. ${ }^{48}$ Categorization is now generally accepted by. all the Justices when reviewing true governmental censorship entailing proscription of speech because of its content; occasional discord is due only to the confusion between censorship and situational restraints. For example, in Bolger v. Youngs Drug Products Corp., ${ }^{49}$ the Court unanimously held that the government could not prohibit the mailing of unsolicited advertisements for contraceptives. The majority opinion did not receive unanimous support only because three Justices wanted to stress their willingness to accept less severe advertising restrictions. ${ }^{50}$

General agreement on the categorization approach to complete proscriptions of messages has greatly aided the Court's application of vagueness and overbreadth doctrines. Because proscription is allowed only for specifically defined categories of speech, a particular statute's scope can easily be compared with the permissible categories. A statute that can be apphed to speech not in one of the categories is overturned. The facts of the individual case are essentially irrelevant to the validity of the statute. ${ }^{51}$

In contrast, because the Court has been unable to define clearly the contextual or environmental factors that will support limited governmental regulation of content, facial review of situational regulations based on overbreadth and vagueness has become considerably muddled. For instance, the Court engaged in overbreadth review of an ordinance prohibiting nude dancing, but not of one zoning adult theaters. ${ }^{52}$ The difference, though the Court did not

48 See New York v. Ferber, 458 U.S. 747 (1982).

6 103 S. Ct. 2875 (1983).

so See id. at 2885 (Rehnquist, J., joined by O’Connor, J., concurring); id. at 2888 (Stevens, J., concurring). Justice Brennan did not participate in the decision. Id. at 2885.

s1 See, e.g., Lewis v. City of New Orleans, 415 U.S. 130 (1974); Gooding v. Wilson, 405 U.S. 518 (1972); Coates v. City of Cincinnati, 402 U.S. 611 (1971). The relationship between first amendment principles defining the scope of permissible speech and the overbreadth principle is explained in Monaghan, Overbreadth, 1981 Sup. Ct. Rev. 1; see generally Note, Overbreadth Review and the Burger Court, 49 N.Y.U. L. Rev. 532 (1974) (criticizing retreat from overbreadth review by Burger Court). For a discussion of the relationship between standing concepts and the vagueness and overbreadth principles, see Sedler, The Assertion of Constitutional Jus Tertii: A Substantive Approach, 70 Calif. L. Rev. 1308, 1326-27 (1982); Sedler, Standing to Assert Constitutional Jus Tertii in the Supreme Court, 71 Yale L.J. 599, 612-26 (1962); see also Note, Standing to Assert Constitutional Jus Tertii, 88 Harv. L. Rev. 423 (1974) (distinguishing standing to assert the constitutional rights of third parties from statutory overbreadth).

${ }^{33}$ Compare Schad v. Borough of Mt. Ephraim, 452 U.S. 61 (1981) (nude dancing), with Young v. American Mini Theatres, Inc., 427 U.S. 50 (1976) (adult theaters). 
articulate it, is that a ban on a form of expression everywhere within a jurisdiction is presumptively censorious, whereas rearranging sites within the jurisdiction is a situational restraint. ${ }^{\text {ss }}$ Failure to make this distinction has done much to confuse the analysis of situational restraints.

\section{B. Speech in Public Places}

Complementing the categorical approach to complete prohibitions on certain messages was the Court's analysis of time, place, and manner regulations of speech. Historically, time, place, and manner analysis concerned incidental restrictions on expressive activities resulting solely from content neutral regulations. ${ }^{54}$

Justice Frankfurter provided an able summary of the Court's early experiences with time, place, and manner regulations in his concurrence in Niemotko v. Maryland. ${ }^{\text {sc }}$ Frankfurter showed that none of the Court's prior holdings indicated that the freedom to speak might depend on location alone. Rather, speech could be regulated in public parks or other governmental facilities if the regulation was compatible with first amendment values. ${ }^{.8}$ Today, the Frankfurter opinion is sometimes overlooked because he ultiinately advocated extreme deference to legislative judgments. ${ }^{57}$ But Frankfurter was surely correct in distinguishing between governmental control of the content of speech and mere control of the form or place of speech. When the government was not acting as a censor, either openly or through a discretionary hicensing standard, Frankfurter noted that first amendment values were not clearly threatened. Nevertheless, even when the regulation was content neutral, absent a substantial governmental interest, he would not have allowed a reduction in the amount of speecl through regulation of its physical impact. Thus, the Court in the 1930's and 1940's justifiably overturned governmental restrictions based

\footnotetext{
ss Justice Blackmun's concurrence in Schad v. Bourough of Mt. Ephraim, 452 U.S. 61 (1981), attempts to make a similar distinction, though without the use of our terminology. Id. at 78.

st See L. Tribe, supra note 30, § 12-20, at 682-83; J. Nowak, R. Rotunda, \& J. Young, supra note 5, at 977-79 (regulation of sound and noise).

${ }^{85} 340$ U.S. 268, 273 (1951) (Frankfurter, J., concurring).

s8 Id. at 282.

${ }^{87}$ Id. at 275-76.
} 
merely on a concern for community tidiness, ${ }^{58}$ but upheld regulations-for example, those aimed at sound trucks or other physical activities-that promoted substantial interests unrelated to censorship. ${ }^{\circ 9}$

When we analyze time, place, and inaimer cases from this perspective-by identifying the issues rather than merely labeling the types of public places-we see the development of a two-step analysis. First, to qualify for time, place, and manner status, a regulation must be content neutral on its face and must not create opportunities for selective application. ${ }^{60}$ Second, if the regulation is truly content neutral, the Court must determine whether the governmental interest advanced is sufficiently important to justify even an incidental restriction on speech.

This two-step analysis can be seen in decisions of two decades ago as well as in decisions of the 1980's. In Tinker $v$. Des Moines Independent Community School District, ${ }^{61}$ the Court analyzed a school's ban on armbands and determmed that, because it was not a true time, place, and manner regulation, it required closer scrutimy. ${ }^{62}$ In United States $v$. O'Brien, ${ }^{63}$ the Court upheld criminal penalties for the destruction of draft registration cards because the law promoted an important interest unrelated to the suppression of expression $^{64}$ (thus indicating that the government's regulations

ss See Schneider v. State, 308 U.S. 147 (1939) (ban on leafletting not justified by desire to control littering).

3s See Kovacs v. Cooper, 336 U.S. 77 (1949) (general regulation of sound trucks upheld); cf. Saia v. New York, 334 U.S. 558 (1948) (ordinance requiring pernission of the police chief for use of amplifiers in public places leld unconstitutional).

Bo Thus, the Court has invalidated discretionary licensing systeins on the theory that sucl systems can mask content-based distinctions. See Sluuttlesworth v. City of Birmingliam, 394 U.S. 147, 150-51 (1969) ("[A] law subjecting the exercise of First Amendment freedoms to the prior restramt of a license, without narrow, objective, and definite standards to guide the licensing autliority, is unconstitutional.") (footnote omitted); Cantwell v. Connecticut, 310 U.S. 296, 304-05 (1940) (ordinance conditioning solicitor's license on official's determination that hicense was to be used for a "rehigious" or a "bona fide" charitable or philanthropic purpose held unconstitutional); Lovell v. Griffin, 303 U.S. 444, 451-52 (1938) (ordinance requiring hicense to distribute literature held unconstitutional); J. Nowak, R. Rotunda \& J. Young, supra note 5, at 973-74.

393 U.S. 503 (1969).

62 Id. at 510-11 (other political symbols were not forbidden, thereby indicating that the regulation was aimed at a particular inessage).

os 391 U.S. 367 (1968). For a discussion of O'Brien, see Ely, supra note 17, at 1483-90.

of Given that Congress may conscript people into the armed forces, Congress has a legitimate interest in preserving useful documentation of ehgibility. 391 U.S. at 377-78. 
were indeed content neutral) and was no more restrictive of speech than necessary to promote this interest (thereby justifying the incidental burden on speech).

The Court has had hittle difficulty in addressing true time, place, and manner issues in the 1980's. In Heffron v. International Society for Krishna Consciousness, Inc., ${ }^{65}$ the Court upheld a restriction on the distribution of literature at the Minnesota State Fair because the law was content neutral, was justified by circumstances at the fair, and allowed ample alternate means of communicating the same message. This analysis is equally valid whether or not the fair is deemed to be a public forum. ${ }^{86}$ Similarly, in United States $v$. Grace, ${ }^{67}$ the Court easily invalidated a law banning picketing and leafletting on the sidewalks surrounding the Supreme Court. The Court found that the law had "an insufficient nexus" time, place, and manner regulation. Thus the Court demonstrated once again that even a content neutral regulation may be invalid if the incidental reduction in the quantity of speech is significant enough to outweigh competing governmental interests.

Grace exemphifies the fundamental irrelevance of public forum analysis to time, place, and manner cases. Significantly, however, the Court found it necessary to hmit its holding to the sidewalks, as opposed to the building's stairs and other areas between the sidewalks and the building. This distinction is consistent with public forum analysis, because although sidewalks are traditional public forums, other areas apparently assimilated into the statute, such as the building's interior, are not. The Court's analysis, how-

os 452 U.S. 640 (1981).

se Although a park is a classic public forum, the Justices had little difficulty uplolding a National Park Service refusal to allow demonstrators to make a public stateinent by sleeping in parks in the center of Washington, D.C. In Clark v. Commumity for Creative NonViolence, $104 \mathrm{~S}$. Ct. 3065 (1984), the Justices, by a 7-2 vote, applied the three-part test used for time, place, or manner restrictions and found that the regulation at issue was content neutral, promoted the government's substantial interest in maintaining the parks, and left open alternative ineans for communication of the message.

67461 U.S. 171 (1983).

68 Id. at 181. The Court noted that appellees' activities apparently did not obstruct the sidewalks or access to the building, threaten injury to any person or property, or interfere witl the administration of the building or grounds. Id. at 182. 
ever, neglects to address the question of why different public places imphicate different governmental interests. ${ }^{69}$

Time, place, and manner analysis has completely broken down in cases in which the government has restricted speech in a specific environment based upon its content or the speaker's identity. ${ }^{\mathbf{7 0}}$ In Cox v. Louisiana (II), ${ }^{71}$ the Warren Court placed its imprimatur on laws restricting commentary on the judicial process in pubhic areas adjacent to courts, relying on a murky distinction between speech and conduct ${ }^{72}$ that made little sense in light of the fact that the state objected as much to the demonstrators' message as to their physical acts. The Court lost sight of the fact that the government may, to protect the judicial process, regulate speech based on its content whether the speech takes place on a sidewalk (a pubhic forum) or in a courtroom (a nonpublic forum), so long as critics of the courts can still voice their opinions in other locations. ${ }^{73}$ The Court in Cox, however, seemed unable to articulate this simple proposition.

The Warren Court further demonstrated its inability to deal with situational regulations in the 1966 decisions of Brown v. Louisiana ${ }^{74}$ and Adderley v. Florida. ${ }^{75}$ In Brown, a fragmented Court reversed the breach of the peace convictions of civil rights demonstrators who had conducted a brief, silent vigil in a public hibrary. In Adderley, the Court narrowly upheld trespass convictions for a peaceful demonstration on a jail driveway. ${ }^{76}$ Surely a government driveway is more like a public forum than a quiet library. The opinions simply fail to explain why the Court found restrictions on speecl more allowable when the speakers were outside the jailhouse, as in Adderley, than when they were inside the public li-

So See Greer v. Spock, 424 U.S. 828, 859-60 (1976).

79 Indeed, the Court's rulings in this area have never been coherent, although until the Burger Court, friendly scholars papered over defects in the Court's opinions. See, e.g., L. Tribe, supra note $30, \S 12-21$, at $688-92$; Kalven, supra note 14 .

71379 U.S. 559 (1965). For commentary on Cox, see Stepban, supra note 8, at 218-23.

72 Cox, 379 U.S. at 563-64.

73 This conclusion will become clear after we introduce our test for situational restraints, infra text accompanying notes 103-18.

74 383 U.S. 131 (1966) (plurality opinion).

78385 U.S. 39 (1966).

76 The only physical conduct involved in Brown was the defendants' standing quietly in the hbrary; presumably the state did not intend to ban completely the combination of noiselessness and an absence of locomotion. In Adderley, an intent to cause "annoyance and vexation" was part of the offense. Id. at 43 n.2. For further discussion of this issue, see $J$. Nowak, R. Rotunda \& J. Young; supra note 5, at 980. 
brary, as in Brown. The important difference between the cases had little to do with the locations, and much more to do with the form of regulation. In Brown, the Court believed that the prosecution was really based on the viewpoint of the speakers and their opposition to segregation, ${ }^{77}$ whereas in Adderley the Court believed that the regulation was entirely content neutral and satisfied the time, place, and manner test. ${ }^{78}$

Classification of public places as various types of forums has only confused judicial opinions by diverting attention from the real first amendment issues involved in the cases. Like the fourth amendment, the first amendment "protects people, not places."79 Constitutional protection should depend not on labeling the speaker's physical location but on the first amendment values and governmental interests involved in the case. Of course, governmental interests are often tied to the nature of the place. Public sidewalks, for example, are generally places where the government's interests are rather weak, given the diverse uses of sidewalks. At the same time, because sidewalks and streets have often served as forums of last resort for those who cannot afford other media of expression, the first amendment interests at stake may be especially high. Consequently, the balance may well tilt in favor of free speech more often when a sidewalk is involved than when some other place is involved..$^{80}$ To this extent, the public forum doctrine

77 See Brown, 383 U.S. at 142-43; id. at 150-51 (White, J., concurring); cf. id. at 149-50 (Brennan, J., concurring) (intimating possible agreement with this point of view but relying on an overbreadth analysis).

${ }^{78}$ For a critique of these opinions, see Note, The Public Forum: Minimum Access, Equal Access, and the First Amendment, 28 Stan. L. Rev. 117, 129-30 (1975). We believe that Adderley was wrongly decided. The statutory requirement of a "mischievious intent" to annoy was inevitably an invitation to viewpoint discrimination. See supra note 76 . Moreover, because tbere was no showing of any actual or impending disruption of jail operations, Adderley seems to be inconsistent with Tinker v. Des Moines Indep. Community School Dist., 393 U.S. 503 (1969), and Cohen v. California, 403 U.S. 15 (1971). Under our focused balancing test, infra text accompanying notes $117-18$, we would overturn the law. A prohibition of trespass with "mischievous intent" to annoy introduces distinctions based on content, and this distinction is only loosely relevant to the admittedly legitimate state interest in preventing disruption of jail procedures.

79 Katz v. United States, 389 U.S. 347, 351 (1967) (fourth amendment).

${ }^{80}$ See generally Kalven, supra note 14, at 13 (citizens have "a kind of First-Amendment easement" to speak on public streets); id. at 30 (discussing speech in street as medium of communication used by the financially disadvantaged); Stone, supra note 12, at 238-245 (discussing the Supreme Court's preservation of "the streets, parks, and similar public places as effective forums for the exercise of First Amendment rights"). 
is a useful heuristic device-a shorthand method of invoking this balance of interest. But when the heuristic device becomes the exclusive method of analysis, only confusion and mistakes can result. $^{\text {si }}$

\section{Realigning First Amendment Standards: A Three-tiered Approach to First Amendment Problems}

\section{A. Content Proscriptions}

The core command of the first amendment is a prohibition on censorship. ${ }^{82}$ This command is most clearly applicable when the government attempts to suppress a message completely by forbidding speakers everywhere in society from communicating it. ${ }^{83}$ Such bans on messages conflict directly with the central values protected by the first amendment. ${ }^{84}$ Whatever the speech may have contributed to the evolution of democratic society is lost, and the "marketplace" value of the speech is irretrievably impaired. ${ }^{85}$ Indi-

s1 The recent prominence of public forum analysis may well relate to the Burger Court's tendency to stress property concepts in first amendment cases. See Dorsen \& Gora, Free Speech, Property, and the Burger Court: Old Values, New Balances, 1982 Sup. Ct. Rev. 195, 226-31; Nowak, Foreword: Evaluating the Work of the New Libertarian Supreme Court, 7 Hastings Const. L.Q. 263, 288, 305-11 (1980).

"2 The Court has often reserved for special condemnation laws "aim[ed] at the suppression of dangerous ideas." Regan v. Taxation With Representation of Washington, $103 \mathrm{~S}$. Ct. 1997, 2002 (1983) (quoting Cammarano v. United States, 358 U.S. 498, 513 (1959), which quoted Speiser v. Randall, 357 U.S. 513, 519 (1958), which quoted in turn American Communications Ass'n v. Douds, 339 U.S. 382, 402 (1950)). On viewpoint regulation as "forbidden censorship," see L. Tribe, supra note $30, \S 12-18$, at 672 n.1; Stene, supra note 4, at 10304; Kalven, supra note 14, at 29; Stone, supra note 18, at 197-200.

As Professor Schauer has noted, the first amendment may have more than one core. See Schauer, supra note 28 , at 240 ("Freedom of speech is more properly regarded as a bundle of different but interrelated concepts, joined together under the oversimphifying rubric of 'freedom of speech.' "); see generally Bollinger, supra note 30 (free speech calls into question how we think about our behefs and the contrary behefs of others; it does not involve sunply access to information for decisionmaking or freedom for self-expression).

ss Furthermore, governmental suppression of speech makes a powerful symbohic statement in favor of suppression and against tolerance. See Bollinger, Book Review, 80 Mich. L. Rev. 617, 630-31 (1982) (reviewing A. Neier, Defending My Enemy: American Nazis, the Skokie Case, and the Risks of Freedom (1979)); see generally Bollinger, supra note 30 (free speech protects society from government regulation by protecting society's right to make decisions through tolerant debate).

s For eloquent judicial statements of this point, see Cohen v. California, 403 U.S. 15, 2426 (1971) (Harlan, J.); FCC v. Pacifica Found., 438 U.S. 726, 772-77 (1978) (Brennan, J., dissenting).

ss See Stone, supra note 18, at 197-98, 217-27. 
viduals lose the ability to endorse the message under any circumstances and thus are denied the "libertarian" value of the first amendment so eloquently articulated by Justice Brandeis. ${ }^{86}$ Here, content neutrality must be the touchstone for first amendment analysis. One need not agree with the absolutist view that content regulation is forbidden in all contexts to agree that the government should not be able to excise a message from society. ${ }^{87}$

Any type of balancing that would allow judges to make a caseby-case determination of the legitimacy of speech would in effect defer to the government precisely where first amendment values indicate it should have the least discretion. ${ }^{88}$ The Court is quite right to demand a truly compelling interest for the complete ehmination of any message or category of speech. Such censorship should be allowed only when necessary to promote an interest so important that it outweighs the core values of the first amendment, or when a particular category of speech is incapable of advancing these values. ${ }^{80}$

These considerations lead to the approach Professor Nimmer first called "definitional balancing,"90 in which the Court uses balancing to define limited categories of unprotected speech. Having identified such a category of speech, the Court does not then allow a case-by-case balancing, but instead gives a precise definition of the type of speech that may be punished. It also demands that laws directly restricting messages be clearly and narrowly drawn to reach only these prohibited categories of speech. ${ }^{91}$ The Supreme

${ }^{88}$ See Whitney v. California, 274 U.S. 357, 375-77 (1927) (Brandeis, J., concurring); sources cited supra note 30 .

${ }^{87}$ See Ely, supra note 17, at 1500-01; Scanlon, A Theory of Freedom of Expression, 1 Phil. \& Pub. Aff. 204 (1972).

${ }^{88}$ See L. Tribe, supra note $30, \S 12-2$, at 583-84.

${ }^{89}$ For an example of the former situation, consider tbe publication during wartime of information about troop convoys. See Near v. Minnesota, 283 U.S. 697, 716 (1931) (dictum). For examples of the latter, consider obscenity, libel, and "fighting words." See L. Tribe, supra note $30, \S 12-8$, at 604-06; Ely, supra note 17, at 1490-93; Schauer, Codifying the First Amendment: New York v. Ferber, 1982 Sup. Ct. Rev. 285, 302, 306; Stone, supra note 18, at 194-97. Even Professor Redish, wbo argues that content discrimination usually should not be an important factor in first amendment analysis, agrees that viewpoint discrimination should invalidate a law. See Redish, The Content Distimction in First Amendment Analysis, 34 Stan. L. Rev. 113, 146 (1981).

${ }^{20}$ See L. Tribe, supra note $30, \S 12-2$, at 583 \& n.21; Shiffrin, Defamatory Non-Media Speech and First Amendment Methodology, 25 UCLA L. Rev. 915, 958-61 (1978).

91 We would apply a similar test when the government attempts to prescribe (rather than 
Court, following the early lead of Justice Harlan, has made its commitment to definitional balancing unmistakable in a series of cases, of which New York v. Ferber ${ }^{92}$ is the most recent notable example.

\section{B. Time, Place, and Manner Restrictions}

The second type of first amendment problem is that of the uniformly applied time, place, and manner regulation. "Public forum" language, like the "speech plus" or "speech yersus action" language of two decades ago, originated in this area..$^{93}$ Time, place, and manner regulations involve governmental restrictions on the physical impact of all speech, regardless of content. So long as the governmental regulation is uniformly applied, regulation of the physical attributes of speech poses relatively little threat to first amendment values; the first amendment's central prohibition on censorship is not strongly implicated. ${ }^{94}$ Although some people may be unable to express themselves in the exact plysical manner, location, or time they find most satisfying, this inconvenience hardly seems a radical intrusion into individual autonomy. Furtlermore, so long as a time, place, and manner regulation does not effectively prohibit all communication of a message, but instead affects only one channel of communication, there is only a shght loss in the social, or "marketplace," values inherent in the first amendment. Thus, a lower level of scrutiny is justified. ${ }^{\circ 5}$

proscribe) speech. In the Court's few encounters with governmental attempts to require people to endorse a point of view that would support governmental positions, not only has the Court required the government to demonstrate a compelling interest, hut it has also indicated that the government quite likely could never make such a demonstration. Ahood v. Detroit Bd. of Educ., 431 U.S. 209, 235 (1977); Wooley v. Maynard, 430 U.S. 705, 717 (1977); West Virginia State Bd. of Educ. v. Barnette, 319 U.S. 624, 642 (1943). Were the Court to confront true "propaganda" rather than "censorship" cases, it would need to employ a content neutrality principle to avoid placing the judicial imprimatur on the elimination of both the societal and libertarian values of the first amendment.

" 458 U.S. 747 (1982).

"s See Kalven, supra note 14, at 21-22. For a summary of the time, place, and manner cases, see J. Nowak, R. Rotunda \& J. Young, supra note 5, at 977-88.

24 See Stone, supra note 18, at 192-93.

os See id. at 192-93. Time, place, and manner regulations may also have a disparate impact on certain viewpoints, but the risk is less than it is for content-based statutes and the need for scrutiny is correspondingly less. See Stone, supra note 4, at 101-03.

The Court demonstrated its commitment to this approach for reviewing time, place or manner restrictions in Clark v. Community for Creative Non-Violence, 104 S. Ct. 3065 
The test for time, place, and manner regulations must perform two functions. First, it must detect content-based restrictions and switch them to a different and more rigorous test. ${ }^{96}$ Second, the test must not allow even content neutral time, place, and manner regulations to reduce substantially opportunities to transmit or receive information effectively.

The three-part test currently employed in time, place, and manner cases is designed to fulfill these functions. In United States $v$. Grace, ${ }^{97}$ the Court succinctly stated the test: "[T] may enforce reasonable time, place, and manner regulations as long as the restrictions 'are content-neutral, are narrowly tailored to serve a significant government interest, and leave open ample

(1984), in which seven Justices found that the National Park Service could refuse permission for a round-the-clock demonstration in a park in Washington, D.C. The demonstrators wished to call attention to the plight of the homeless by sleeping in symbolic "tent cities" in the park. The majority found that the refusal to allow such a demonstration was a valid time, place, or manner restriction because (1) it was a content neutral means of promoting the government's interest in preserving park lands, and (2) it allowed adequate alternative cliannels of communication. Although the refusal to allow the "sleep in" decreased the forcefulness of the message, the Justices beheved that the three-part standard of review, which admittedly involves some deference to other branclies of government, was sufficient to protect the first amendment values in this case. As the majority opinion stated:

We do not believe [contrary to the Court of Appeals], however, that either United States $v$. O'Brien or the time, place, and manner decisions assign to the judiciary the authority to replace the Park Service as the manager of the Nation's parks or endowed the judiciary witl the competence to judge how mucl protection of park lands is wise and how that level of conservation is to be attained.

$104 \mathrm{~S}$. Ct. at 3072 (footnote omitted).

96 The "switching" metaphor seems to have originated with Ely, supra note 17, at 1484 . The Court does not currently apply time, place, and manner analysis to nonpublic fora, see United States Postal Serv. v. Council of Greenburgh Civic Ass'ns, 453 U.S. 114, 132 (1981), but it does require regulations to be content neutral and reasonable, id. at $131 \mathrm{n} .7$. Justice Rehnquist has argued that in nonpublic fora, the mere potential for discriminatory application of a regulation slould not render it invalid; an actual case of content discrimination must be established. See Dallas County Hosp. Dist. v. Dallas Ass'n of Community Orgs. for Reform Now, 459 U.S. 1052, 1054 (1982) (Justice Rehnquist dissenting from derrial of certiorari but offering no reason for this public/nonpublic distinction other than admisistrative convenience).

Content discrimination may also emerge where the government's purported concern with public order would in effect give those disagreeing with the speech a "heckler's veto." See Edwards v. South Carolina, 372 U.S. 229, 237 (1963) (civil rights demonstrators could not be convicted for "breach of the peace" where the evidence "showed no more tban that the opinions they were peaceably expressing were sufficiently opposed to the views of the majority of the community to attract a crowd and necessitate police protection").

${ }^{\circ 7} 461$ U.S. 171 (1983). 
alternative channels of communication." "98 The first part of the Grace test excludes cases involving content discrimination; these cases require scrutiny under more demanding tests. The other two parts of the test are designed to ensure that the governmental regulation does not unduly restrict the channels of communication. ${ }^{98}$

Essentially the same test applies to all content neutral regulations regardless of the nature of the forum, as the Court's opinion in Members of the City Council of Los Angeles v. Taxpayers for Vincent ${ }^{100}$ indicates. Taxpayers for Vincent involved a political candidate who claimed a right to place campaign signs on street light posts in violation of a local ordinance. The majority opinion by Justice Stevens noted that light posts are not a type of government property traditionally designated for pubhic communication and hence do not constitute a public forum. ${ }^{101}$ The opinion also indicated, however, that the restriction on posting signs on the property of others would be valid whether it was applied in public forum or nonpublic forum situations. Regardless of the categorization of the environment in which the restriction was applied, the Court was satisfied that this was a legitimate time, place, or manner restriction on speech. ${ }^{102}$

\section{Situational Restrictions.}

Not surprisingly, judges tend to examine all first amendment issues as if they involve only the basic content-prohibition problem or the basic time, place, and manner problem. ${ }^{103}$ Unfortunately,

* Id. at 177 (quoting Perry Educ. Ass'n v. Perry Local Educators' Ass'n, 460 U.S. 37, 45 (1983)). We advocate using this test not only for a public forum, but also for content neutral regulations cutting off public access to other government facilities such as bulletin boards. The Grace test offers the government considerably more discretion in closing such facilities to the public than the comparable test proposed in Stone, supra note 12, at 258-61.

* A somewhat similar access test was proposed in Note, supra note 78, at 135-38. Unlike a later Stanford note, however, we would not require a "compelling" justification for such regulations. See Note, A Unitary Approach to Claims of First Amendment Access to Publicly Owned Property, 35 Stan. L. Rev. 121, 144-47 (1982).

100104 S. Ct. 2118 (1984).

101 Id. at 2134.

${ }^{102}$ Id. at 2134 n.32.

${ }^{102}$ For example, the dissents in FCC v. Pacifica Found., 438 U.S. 726 (1978), and Young v. American Mini Theatres, Inc., 427 U.S. 50 (1976), reveal the Supreme Court's inability to distinguish between banning speech entirely or zoning it to certain locations or times. For other examples of judicial inability to discern the distinctive features of situational restraints, see supra text accompanying notes 52-53, 74-81. 
not all issues fit this simple dichotomy. A third problem area involves situational restraints; that is, regulations based on a hink between a defined category of speech and its harmful effects on a specific environment. When such an environmental impact exists, the government may regulate content in that environmental context only as long as its goals are unrelated to censorship and it does not restrict the flow of ideas in society as a whole..$^{104}$

The test for situational restraints must give great weight to first amendment values but at the same time leave room for legitimate governmental interests. The test also must give little deference to the nonjudicial branches of government in the crucial determination of whether the government's goal is consistent with first amendment values. More deference is justifiable when determining the "fit" between the goal and the choice of means. To distinguish this test from both the definitional balancing required for content proscriptions and the ad hoc balancing required for time, place, and manner regulations, we will call it "focused balancing."

Focused balancing initially requires a court to determine the government's goals in passing the challenged situational restraint. Several limitations should apply to the government's attempts to justify the restrictions. First, the government's goal should be clearly articulated by the lawmaker and not by an after-the-fact rationalization. This requirement helps ensure that censorship is not the primary purpose of the regulation. It also gives courts the benefit of a clearly articulated legislative determination that the goal does indeed justify the given restriction on speech. ${ }^{105}$ Second, the goal must relate to the specific situation and to the kind of speech being regulated. ${ }^{106}$ If the governmental regulation bans a

${ }^{104}$ We classify as situational restraints those instances in which the government rehes on its special relationship with public employees as a basis for regulating their speech. In this context, the Court concedes that the government may be properly concerned with the content of speech. See Connick v. Myers, 461 U.S. 138 (1983).

${ }^{105}$ Professor Kalven stressed this point. See Kalven, supra note 14, at 32; see also Schad v. Borough of Mt. Ephraim, 452 U.S. 61, 83-84 (1981) (Stevens, J., concurring) (municipality's zoning plan could specifically prohibit live nude dancing, but broad zoning law would force community to prove the activity is inconsistent with its zoning goal); Farber, supra note 8, at 738-39 (drawing analogy between gender and illegitimacy classifications and first amendment content regulation: the asserted purpose must be plausible in light of the legislative history and the circnmstances surrounding enactment). For a discussion of the importance of the motive underlying such restrictions, see Stone, supra note 18, at 227-33.

${ }^{108}$ In Railway Express Agency v. New York, 336 U.S. 106 (1949), a New York City ordinance forbade trucks from carrying any advertisements unless the truck was a dehvery vehi- 
certain type of speech in schools, the government goals should relate to schools and to the effects of the regulated speech in the school environment, and not to the general undesirability of certain kinds of speech. Again, this serves as a check on improper motivation and ensures a focused legislative judgment. Third, and most important, the goal itself must be permissible.

This third limitation is the most difficult to articulate. It is tempting to agree with several Justices that the goal must be viewpoint neutral; that is, it must be unrelated to government disagreement with a certain viewpoint. ${ }^{107}$ Viewpoint neutrality is generally required, but significant exceptions exist. It seems reasonable, for example, for public schools to allow the teaching of orthodox geography but not the "flat earth" theory. ${ }^{108}$ The government may prohibit secondary boycotts connected to labor-management disputes to channel those disputes through the labor negotiation and mediation process, ${ }^{109}$ but it may not impose economic sanctions agaimst social issue boycotts in which it lacks a sufficiently important interest to justify restrictive action. ${ }^{110}$ Without trying to provide a hitmus test for detecting permissible governmental goals, we would simply say that the goal must be consistent with first amendment values or, as the Court has sometimes said, "unrelated to the suppression of free expression."111

cle owned and operated by the advertised business. There was no effort by the government to relate its asserted goal of reducing traffic hazards to the different treatment accorded to different advertisers. Although the equal protection clause, and not the first amendment, was the issue, the concerns mentioned in Justice Jackson's concurring opinion are especially appropriato when considering situational restraints on protected speech. Id. at 112-15 (Jackson, J., concurring).

${ }_{102}$ See Perry Educ. Ass'n v. Perry Local Educators' Ass'n, 460 U.S. 37, 57-62 (1983) (Brennan, J., dissenting).

${ }_{108}$ See Schauer, supra note 28 , at 243 (when teachers "speak" in the classroom, they do 80 as public employees, not as private citizens). One might deal with this problem by carving out a special exception to viewpoint neutrality for government officials in light of the "government's interest, qua government, in speaking clearly and definitively." Perry Educ. Ass'n v. Perry Local Educators' Ass'n, 460 U.S. 37, 61 n.5 (1983) (Brennan, J., dissenting); see L. Tribe, supra note $30, \S 12-4$; Note, supra note 9 , at 1867-68. Recognition of such a broad exception, however, would appear to leave no room for any concept of academic freedoin. Like Schauer, supra note 28 , at 249 , we believe the first annendment should provide some room for academic freedom.

${ }^{100}$ See NLRB v. Retail Store Employees Union, Local 1001, 447 U.S. 607, 616 (1980) (dismissing a claim that secondary labor boycotts have first amendment protection).

${ }^{110}$ See NAACP v. Claiborne Hardware, 458 U.S. 886 (1982).

${ }^{111}$ United States v. O’Brien, 391 U.S. 367, 377 (1968). For example, although the govern- 
If the government can estabhish that the speech singled out for special regulation has a truly distinctive impact on a permissible governmental goal, the Court must then determine whether that goal is important enough to justify the burden it places on the speech. The balancing methodology here must be tailored to the problem. The ad hoc balancing used in time, place, and manner problems would give too hittle weight to the dangers of contentbased restrictions. The government might well achieve large-scale censorship by small steps in many separate contexts, each appearing reasonable by itself. On the other hand, the definitional balancing appropriate to true censorship cases would effectively eliminate society's ability to pursue important, legitimate interests. ${ }^{112} \mathrm{~A}$ hybrid of these two tests is needed.

This hybrid test must have two important characteristics. First, it should not weigh merely the interest of the individual plaintiff before the court. It is all too easy to conclude that the loss of any one individual's speech is inconsequential in the face of a reasonable governmental goal. Instead, the court must require the government to articulate in advance which classes of speech it intends to regulate. The question must be whether the burden on the entire class of speech is outweighed by the government's goal. ${ }^{113}$ Requiring the government to proceed through clear, exphcit regulation also prevents ad hoc administrative decisionmaking under the

ment might forbid teaching the flat earth theory in its schools, it could not forbid the theory's proponents from lecturing in the park or publishing a "Flat Earth Journal." The latter prohibitions would be made out of hostility to the theory, with the aim of suppressing it; the former, more limited, restriction serves the government's interest in effective education. The government's interest as educator, however, would not extend to other educators' practices, so the state could not prevent private schools from teaching the flat earth theory. Cf. Pierce v. Society of Sisters, 268 U.S. 510 (1925) (state statute requiring children to attend public school not enforceable against private schools); Meyer v. Nebraska, 262 U.S. 390 (1923) (state cannot prevent instruction of German language in parochial school). The state may, however, have a futher interest in seeing that children are exposed to a body of commonly held behefs and knowledge on the ground that society benefits if its inembers are able to communicate freely. The state may, therefore, require that graduates of the Flat Earth Academy know the orthodox theory.

11 See L. Tribe, supra note $30, \S 12-19$, at 679 ; Note, supra note 9, at 1858.

113 In this respect, our test resembles defmitional balancing. This requirement helps assure clear notice of the limits of permissible expression. By requiring consideration of the entire class of speech that is being penalized, it also tends to prevent restrictions on speech from being dismissed as trivial, as in several of Justice White's latest opmions. See Connick v. Myers, 461 U.S. 138 (1983); Perry Educ. Ass'n v. Perry Local Educator's Ass'n, 460 U.S. 37 (1983). 
guise of situational regulation from becoming a cover for outright censorship. ${ }^{114}$ Second, in balancing the interests, the court must keep im mind the "profound national commitment"11s to free speech, even speech that is irritating and offensive. The court must perform its balancing with what Harry Kalven has called "a weight of enthusiasm for the personal rights involved."116

To summarize, the focused balancing test apphies only to situational restraints, which are defined as restrictions keyed to content but apphicable only in limited contexts. The test can be stated in terms of three major components:

1. The Articulation Requirement. The test stresses specificity and clarity as requirements of regulation. Thus, the government must clearly articulate: (a) precisely what speech is permissible in the context covered by the regulation; (b) what goals the regulation seeks to achieve; and (c) how those goals are distinctively related to the context and the affected category of speech.117

2. The Permissibility Requirement. The goals specified by the government must themselves be consistent with first amendment values. Usually, this will require that the goal be viewpoint neutral-that it not favor any one viewpoint over any other.

3. The Balancing Requirement. Having passed the threshold tests, the regulation must still be shown to serve a governmental interest that outweighs its impact on speech. This requires a scrutiny of the relationship between the regulation and the government's goals to determine whether the regulation is reasonably likely to attain the goal. ${ }^{118}$ It also requires a determination of whether the goal is important enough to justify the means.

114 This is a well recognized concern with discretionary time, place, and manner licensing. See infra text accompanying notes 171-76.

118 New York Times Co. v. Sullivan, 376 U.S. 254, 270 (1964).

110 Kalven, supra note 14, at 16; see also Farber, supra note 8, at 748 (suggesting that balancing be done "with a sensitivity to first amendment values and an awareness of precedent"); Redish, supra note 89, at 145 (agreeing with Kalven that "a 'thumb on the scales' in favor of free speech" is protection against government abuse) (quoting Kalven, supra note 14 , at 28 ).

117 See Scliad v. Borougl of Mt. Ephrann, 452 U.S. 61, 83 (1981) (Stevens, J., concurring), for a statement of articulation requirements.

11s Again, to refer to Justice Jackson's concurrence in Railway Express Agency v. New York, 336 U.S. 106 (1949), "the differentiation must have an appropriate relation to the object of the legislation or ordinance." Id. at 115 (Jackson, J., concurring). A regulation that distinguishes among kinds of speech but that promotes no legitimate governmental interest consequently is not "appropriate." Id. 
Some may complain that this test ultimately turns on each Justice's vision of first amendment values and the strength of the Justice's attachment to such values. ${ }^{119}$ We have two responses. First, attempts to work out formalistic tests to be apphed by judges witbout heed to their own values have proved unsuccessful. The Court has simply been unable to write intelligible majority opinions using the rigid categories of the public forum doctrine or strict content neutrality. ${ }^{120}$ Second, our own view is that judges simply cannot escape from value judgments. No test, however mechanical in its statement, no precedent, no legislative history can constrain a decision so effectively as to ehminate entirely the values of the deciding judge in hard cases. ${ }^{121}$ Some scholars argue that articulating values is the most important part of the judicial function, ${ }^{122}$ but in any event, judges inevitably must apply their own values. Moreover, a constitution so mechanical that it could be applied by judicial automatons might well be thought too dehumanized to be worthy of allegiance.

If judges are to apply their own values, they must articulate those values and explain their relevance to decisions in particular cases, rather than manipulate tests that purport to be value free. Only if lower courts can understand the true grounds of decisions can they follow precedent in a principled manner. More important, if the Court does not articulate its own grounds for decisions, it will never have to think about them.

The test proposed in this article is not value free. It presupposes certain values underlying the first amendment, values not everyone shares. To say that they are values is not to say that we have no reasons for holding them, but discussion of our pohtical philoso-

${ }^{110}$ See Note, supra note 9, at 1861 ("a judgment based on content and value . . . is unlikely to provide secure protection for unpopular expression") (footnote omitted). It is rather trendy these days to attempt to deduce all of first amendment law from a single principle or value. Professor Schauer has ably pointed out the futility of this attempt. See Schauer, supra note 89, at 308-14.

${ }^{120}$ Cf. Van Alstyne, A Graphic Review of the Free Speech Clause, 70 Calif. L. Rev. 107, 139-42 (1982) (no formula for reading the first amendment avoids problems of judicial discretion).

${ }^{121}$ See Nowak, Resurrecting Realist Jurisprudence: The Political Bias of Burger Court Justices, 17 Suffolk U.L. Rev. 549 (1983); Tushnet, Following the Rules Laid Down: A Critique of Interpretivism and Neutral Principles, 96 Harv. L. Rev. 781 (1983).

${ }^{122}$ See, e.g., M. Perry, The Constitution, The Courts, and Human Rights: An Inquiry into the Legitimacy of Constitutional Policymaking by the Judiciary (1982); Fiss, The Supreme Court, 1978 Terın-Foreword: The Forms of Justice, 93 Harv. L. Rev. 1, 51 (1979). 
phies is outside the scope of this article. More important for present purposes is whether the test also reflects values that appear to underlie Supreme Court opinions. Adoption of our test would not require the Justices to change their own first amendment values, but would enable them (and the rest of the world) to see more clearly how those values relate to decisions in particular cases.

The test also has enough structure not to leave lower courts totally adrift nor to require the Supreme Court to plumb the depths of political philosophy every time it decides a case. Many cases will involve either straightforward censorship or time, place, and manner restrictions. Others will fail the initial part of our focused balancing test due to the government's inability to point to an articulated, distinctive governmental interest closely tied to the regulation. Only in the relatively unusual case where a situational regulation passes these prehminary tests will the Court be required to confront its first amendment conscience. ${ }^{123}$

\section{Applying the Focused Balancing Test: The Public School Cases}

In attempting to apply the preceding analysis to a series of cases involving the public schools, we hope not only to make our analysis more concrete but also to illustrate wlyy these cases involve essentially similar issues and should receive a unitary treatment.

The first significant public scliool case was Tinker $v$. Des Moines Independent Community School District. ${ }^{124}$ In Tinker, school principals learned of a student plan to wear black armbands to class as a protest against the Vietnam war. The principals anticipated the intended protest by issuing an order banning the wearing of any armbands to scliool. The authorities apparently believed that student discussion of such controversial issues in the scliools was inappropriate. ${ }^{125}$ The Court, over a veliement dissent from Justice Black, ${ }^{128}$ lield that the ban was improper absent a showing

\footnotetext{
123 For further discussion of the need to limit the use of unstructured balancing, see Farber, supra note 8 , at 748 n.102.

124393 U.S. 503 (1969). For a critical commentary on Tinker, see Diamond, The First Amendment and Public Schools: The Case Against Judicial Intervention, 59 Tex. L. Rev. $477,478-510$ (1981).

${ }^{128} 393$ U.S. at 509-10 \& nn.3-4. Justice Harlan noted in dissent that there was no evidence of viewpoint discrimination. Id. at 526.

${ }^{123}$ Id. at 515-26 (Black, J., dissenting) ("II]t is the beginning of a new revolutionary era of permissiveness in this country fostered by the judiciary.").
} 
that the student protest would " materially and substantially interfere with the requirements of appropriate discipline in the operation of the school." "127 The Court then found that the government had failed to demonstrate any link between the restriction on speech and the legitimate governmental interest in maintaining an effective educational process. Notably absent from the opinion is any discussion of whether the school's hallways and classrooms constituted a pubhic forum, and the Court found it unnecessary to rest its decision on any per se rule against content discrimination by schools. The type of inquiry conducted by the Tinker court is consistent with that suggested by our focused balancing test for situational restraints. The school's failure to show that the armbands would interfere with school activities indicates that the prohibition of armbands is not "reasonably hkely" to contribute to maintaining a necessary degree of order..$^{128}$

The next significant decisions in this area came when the Court considered the validity of restrictions on picketing outside schools. The two cases, Police Department of Chicago v. Mosley ${ }^{129}$ and Grayned v. City of Rockford, ${ }^{130}$ involved identical forums, and in both cases the Court held unconstitutional a ban on picketing that exempted labor picketing. ${ }^{131}$ In Grayned, however, the Court up-

127 Id. at 509 (quoting Burnside v. Byars, 363 F.2d 744, 749 (5th Cir. 1966)); accord Widmar v. Vincent, 454 U.S. 263 , $276-77$ (1981); Healy v. James, 408 U.S. 169, 188-89 (1972); see also Tinker, 393 U.S. at 510-14 (explaining that students have a first amendment right to express any point of view as long as they do not disrupt school activities).

128 See supra text accompanying note 117 (articulation requirement of proposed focused balancing test).

199408 U.S. 92 (1972). For further discussion of Mosley, see Farber, supra note 8, at 73337.

130 408 U.S. 104 (1972). For an enthusiastic endorsement of Grayned as an approach to pubhic forum law, see Stone, supra note 12, at 250-52. The Grayned opinion also overturned convictions under a provision containing a labor exemption hike that in Mosley. Justice Schaefer's dissent in Grayned in the state court foreshadowed the Court's holding in Mosley. See City of Rockford v. Grayned, 46 Ill. 2d 486, 263 N.E.2d 866, 869 (1970) (Schaefer, J., dissenting).

${ }_{131}$ The Mosley opinion analyzed the Chicago statute, which exempted from its general ben on picketing next to a school "the peaceful picketing of any school involved in a labor dispute," 408 U.S. at 94 n.2, under the first and fourteenth amendments. Id. at 95 . In the words of Justice Marshall, writing for the Court, "The central problem with Chicago's ordinance is that it describes permissible picketing in terms of its subject matter." Id. He rejected the assertion that the ordinance was a reasonable time, place, and manner regulation on this same ground. Id. at 99 . Consequently the ordinance was not cohtent neutral, and justification of its restrictions required close tailoring to substantial governmental interests. 
held convictions under a municipal antinoise ordinance on the ground that the ordinance represented a reasonable time, place, and manner regulation of expressive activity. ${ }^{192}$ These cases teach that the government may not exempt labor picketing froin a total ban on picketing near public schools, but that it may prohibit all activities that disturb the operation of the schools. The law invalidated in Mosley exempted labor picketing, but was clearly not an attempt to censor all nonlabor speech. It is hardly plausible to assume that the regulation reflected hostility to all nonlabor speech or was part of a campaign to excise all nonlabor speech from public discourse. ${ }^{133}$ Hence, it is inappropriate to characterize Mosley as an ordinary censorship case to which the categorical approach should apply. Similarly, Grayned does not fit readily into time, place, and manner analysis. The restriction involved there was not a general "disturbing the peace" statute but an "antinoise" ordinance that covered all "diversions" interfering with school operations, and as a result it was not clearly content neutral. ${ }^{194}$ Thus, neither a strict content neutrality requirement, which would equate the labor exemption with censorship of nonlabor speech, nor the time, place, and manner test, which would address only the physical aspects of speech, is fully applicable to these cases. ${ }^{135}$

Id.

The Grayned Court spent little effort analyzing Rockford's antipicketing ordinance, finding it identical to the Chicago ordinance held unconstitutional in Mosley and likewise invalid as a violation of the equal protection clause of the fourteenth amendinent. Grayned, 408 U.S. at 107.

${ }^{122}$ Grayned, 408 U.S. at 115-18.

323 See Stephan, supra note 8, at 226.

134 Both the United States Supreme Court, see Heffron v. International Soc'y for Krishna Consciousness, Inc., 452 U.S. 640, 648 n.10 (1981), and commentators, see Stone, supra note 12, at 244-45, have read Grayned as a time, place, and manner case. The key reason for upholding the ordinance was not, however, that it constituted a general restriction on the level of noise, but that it regulated the impact of speech on school activities. Grayned, 408 U.S. at 117-20. Although some passages suggest that the Court viewed the ordinance as content neutral, id. at 120 , the Court's interpretation of diversionary activities prohibited by the ordinance is broad enough to encompass considerations of content, id. at $111 \mathrm{n.16}$, and at least one of its examples of prohibited conduct lias a clear content basis. Id. at 119 ("boisterous demonstrators who ... . incite children to leave the schoolhouse").

128 This also explains the Grayned Court's heavy reliance on Tinker v. Des Moines Indep. Community School Dist., 393 U.S. 503 (1969). Grayned, 408 U.S. at 117-21. Such rehance seems inexplicable if the Court perceived Grayned as presenting a completely different issue because it involved a public forum. But far from viewing the cases as unrelated, the Grayned Court called Tinker the "touchstone" of its analysis. Id. at 117. 
Moreover, under formal public forum analysis these cases appear to have nothing in common with Tinker, which involved the interior of a school building, a nonpubhic forum. Yet our analysis makes it clear that Grayned, Mosley, and Tinker are congruent. In each case, the government's asserted interest was in preventing disruption of the educational process. ${ }^{136}$ This interest is a legitimate state purpose distinctively related to the functioning of pubhic schools. The differing results in the cases simply follow from the fact that in Grayned the restriction was directly keyed to this interest, whereas in Tinker no threat to this interest had been shown, and in Mosley the hines drawn by the regulation had no relationship to the asserted purpose. ${ }^{137}$

Widmar $v$. Vincent $t^{138}$ demonstrates both the analytical congruence of the Grayned, Mosley, and Tinker cases and the need to abandon public forum analysis. In Widmar, the Court invalidated a state university regulation that made classroom and other facilities available to registered student groups but prevented the facilities from being used for religious teaching or worship. Justice Powell, writing for the majority, found that "[l1]aving created a forum generally open to student groups ... . [the university's regulation] violates the fundamental principle that a state regulation of speech should be content-neutral."1s9 Justice Powell made some attempt to examine the first amendment values at stake in this case by demonstrating that the university's regulation did not further the constitutional values inlerent in the separation of church and

\footnotetext{
138 Regulation of a teacher's speech is allowed only to avoid disruption of the school/ teacher working relationship. This can be seen inferentially in Givhan v. Western Line Consol. School Dist., 439 U.S. 410 (1979), where the Court unanimously reinstated a public school teacher who was discharged for privately criticizing her working conditions and for forwarding her opinions on employment and public issues to her employer. See also Pickering v. Board of Educ., 391 U.S. 563 (1968) (improper to dismiss a public school teaclier for writing a letter to a local newspaper criticizing the board's allocation of scliool funds).

${ }^{137}$ Thus the results in the cases are consistent with, and in fact flow easily from, our focused balancing test. The regulation in Mosley fails the test not simply because the distinction between types of picketing is unrelated to the goal of preventing disruption of the school day. The exception for labor picketing would be legitimate if it in turn served a legitimate purpose. For example, allowing labor picketimg would be justified if the NLRB required the exception; it would not be justified simply by a preference for labor unions. Our rationale provides a common sense basis for these decisions, but the opinions them. selves verge on arid exercises in formalism.

138454 U.S. 263 (1981).

139 Id. at 277.
} 
state. His opinion was restricted, however, by the need to employ public forum analysis. He could not call the school a "nonpublic forum" for fear that such language would indicate that the government could prohibit speech in a school on the basis of government disapproval of the message being conveyed. Yet categorization of the school as a "pubhic forum" would make it appear that the government could employ no content-based distimctions there and that first amendment values were impaired when a teacher disciplined a student in history class for talking about the World Series-an action that is certainly not content neutral. ${ }^{140}$ Powell therefore equivocated, noting that the campus "possesses many of the attributes of a public forum"141 and stating the holding in terms of "a forum generally open to student groups."142

Under our proposed focused balancing test, the result in Widmar is quite consistent with earher decisions. The government was unable to articulate why religious speech had a special impact on the school environment when classrooms were not being used for school activities. Once the Court concluded that restriction of rehigious speech was not necessary to promote the separation of church and state required by the first amendment, the government's interest evaporated. When a teacher regulates discussions in the classroom, however, the government can articulate with specificity the goal of efficient education, which is distinctively related to the context and which does not favor one viewpoint over another, and the government can further demonstrate that its regulation is reasonably tailored to promote goals that outweigh its minimal impact on speech. Because he rejected pubhic forum analysis, Justice Stevens, concurring in Widmar, could address the first amendment values at stake in a manner quite similar to the approach advocated in this article. ${ }^{148}$

Perhaps no important first amendment case in recent years has given the Supreme Court as much trouble as Board of Education

${ }^{140}$ See Consolidated Edison Co. v. Public Serv. Comm'n, 447 U.S. 530, $544-45$ (1980) (Stevens, J., concurring).

111 Widmar, 454 U.S. at 267 n.5.

${ }^{142}$ Id. at 277. This intermediate position was later incorporated into the Court's public forum doctrine. Perry Educ. Ass'n v. Perry Local Educators' Ass'n, 460 U.S. 37, 46 n.7 (1983).

143 454 U.S. at $277-78$ (Stevens, J., concurring). 
v. Pico, ${ }^{144}$ in which the Court considered a school board's order removing nine books from secondary school libraries. The board explained that the books, several of which were written by noted autlors, ${ }^{145}$ were "anti-American, anti-Christian, anti-Semitic, and just plain filthy," and concluded that it had a duty to "protect the children in our schools from this moral danger." 146 The books were also deleted from the curriculum, which meant that they could be discussed in class but that teacliers could not recommend them to students. ${ }^{147}$

The issue before the Supreme Court was whether the school board was entitled to summary judgment in a case challenging the board's authority to remove books from the school system due to their content. To say the Court was fragmented is an understatement: the case produced seven separate opinions. ${ }^{148}$ Justice Brennan, writing for himself and Justices Marshall and Stevens, argued that "school boards may not remove books from school hbrary slielves simply because they dislike the ideas contained in those books." "19 Justice Blackmun would have reversed the board only if it had been motivated by "partisan or political reasons." "150 Justice White preferred not to reacl the first amendment issue until after the facts had been clarified at trial. ${ }^{181}$ The remaining four Justices were all willing to give the board virtually complete discretion over the library's contents. ${ }^{182}$

144457 U.S. 853 (1982). For a review of the lower court cases on this issue, see Diamond, supra note 124 , at $510-12,518-24$.

148 The nine books were Slaughterhouse Five, by Kurt Vonnegut, Jr.; The Naked Ape, by Desmond Morris; Down These Mean Streets, by Piri Thomas; Best Short Stories of Negro Writers, edited by Langston Hughes; Go Ask Alice, anonymous; Laughing Boy, by Oliver LaFarge; Black Boy, by Richard Wright; A Hero Ain't Nothin' But A Sandwich, by Alice Childress; and Soul On Ice, by Eldridge Cleaver. 457 U.S. at 856 n.3.

148 Id. at 857.

147 Id. at 858 \& n.12.

148 Id. at 855 (Brennan, J., joined by Marshall, J. and Stevens, J.); id. at 875 (Blackmun, J., concurring in part); id. at 883 (White, J., concurring); id. at 885 (Burger, C.J., joined by Powell, J., Rehnquist, J., and O'Connor, J., dissenting); id. at 893 (Powell, J., dissenting); id. at 904 (Rehnquist, J., jomed by Burger, C.J. and Powell, J., dissenting); id. at 921 (O’Connor, J., dissenting).

149 Id. at 872.

130 Id. at 879.

${ }^{151}$ Id. at 883-84. Presumably, Justice White thought the first amendment claims sufficient to deserve a full hearing.

${ }^{162}$ In dissent, Chief Justice Burger, joined by Justices Powell, Rehnquist and O'Connor, argued that the Court was "perilously close to becouning a 'super censor.' " Id. at 885 . The 
Under our proposed analysis, Pico is a relatively straightforward case. ${ }^{153}$ Under the focused balancing test, the first step is to determine what governmental interests were asserted by the lawmaking body and what standard it apphed. Arguably, the lack of a sufficiently articulated standard for deciding which books to ban is in itself sufficient to decide Pico. By engaging in ad hoc decisionmaking without any clear standard, the board left its authority open to the same kinds of abuse the Court has condemned in a host of time, place, and manner cases. ${ }^{154}$ Putting that aside, the two objections to the books seem to have been: (1) that they expressed offensive ideas dangerous to children; and (2) that they contained offensive language dangerous to children. ${ }^{155}$ Conspicuously absent were a number of other possible explanations that might in other contexts justify restrictions on hbrary books-for example, that the money would be better spent on other books ${ }^{156}$ (not an issue since the books had already been purchased), that the school was reinforcing parental decisions concerning suitability, ${ }^{157}$ that young

dissenting Justices emphasized that the books were easily available elsewhere, id. at 886 , and cautioned that, in essence, the plurality opinion suggests that "if a writer has something to say, the government through its schools must be the courier." Id. at 887 . The dissenting Justices concluded that courts may not interfere with the role of the school in providing appropriate guidance to students:

Presumably all activity within a primary or secondary school involves the conveyance of information and at least an implied approval of the worth of that information. How are "fundamental values" to be inculcated except by having school boards make content-based decisions about the appropriateness of retaining materials in the school hibrary and curriculum.

Id. at 889.

${ }^{163}$ Our theory does not address one point that divided the Justices. Justice Brennan's plurality opinion apparently viewed the case as involving the students' right to receive information. Id. at 868 . In dissent, the Chief Justice argued that such a right could only exist in the presence of a willing speaker, a circumstance absent in Pico. Id. at 887-89. Assuming that librarians have some claim to academic freedom, we think a school hibrarian could well assert the right to be free of ideological restrictions in ordering books, though not of responsibility for the exercise of judgment in the pursuit of this freedom.

1se See supra note 60 and accompanying text.

${ }^{185}$ See supra text accompanying note 146.

166 See Widmar v. Vincent, 454 U.S. 263, 277 (1981) (Stevens, J., concurring) (discussing a university's need to establish priorities on how to spend limited resources). This factor supports the plurality's view that book purchasing imphicates considerations significantly different than those involved in a case of removing books from the shelves. See Board of Educ. v. Pico, 457 U.S. 853, $871-72$ (1982) (Brennan, J.); id. at 878 n.1 (Blackmun, J., concurring in part).

${ }^{157}$ A parental consent requirement could have appeased this concern. Indeed, the board did adopt such a requirement for one book. Pico, 457 U.S. at 858. Arguably, the board's 
children might think that all materials in the school library were endorsed by the schools, ${ }^{158}$ or that some disruption of the educational process seemed hikely. ${ }^{159}$

The two goals the board asserted fail to satisfy the requirements of our test. ${ }^{160}$ To begin with, they have no particular relationship with the hibrary in particular or the school in general; essentially, they would apply just as well to a student lending another student the books, to a public library making the books available, or even to a bookstore selling the books to minors. The necessary link between the state's goals and the situational restriction is therefore lacking. Furthermore, one of the state's goals, suppressing offensive ideas, seems clearly impermissible under the first amendment. As Tinker made clear, the mere fact that ideas are controversial or offensive does not justify their elimination from the schools. ${ }^{161}$ The other goal, that of denying children access to books containing offensive language, may not be impermissible, at least if FCC $v$. Pacifica Foundation is to be believed. ${ }^{162}$ On the other hand, even if this had been the articulated goal and the regulation had been carefully crafted to achieve it, the board's definition of offensiveness seems to have been extraordinarily broad. If offensive means "any work containing any profanity," the goal of protecting students from exposure to dirty words hardly seems to be sufficient to justify denying them access to much of Western hiterature, including even the Bible. ${ }^{183}$

Indeed, unless some talismanic significance is placed on the

blanket ban on the other books impaired parental rights to allow such access. Cf. Bolger v. Youngs Drug Prods. Corp., 103 S. Ct. 2875, 2884-85 (1983) (holding unconstitutional a statute prohibiting the delivery by mail of unsolicited advertising for contraceptives; the statute proscribed information relating to an important parental decision).

${ }^{168}$ See Diamond, supra note 124 , at 514. The case involved only high school and junior high school students. Pico, 457 U.S. at 856-57. Perhaps one might make a case for separate treatment of the junior high school, but the board apparently made no such claim.

${ }^{188}$ See supra text accompanying notes 136-37. No showing of any disturbance was made in Pico.

${ }^{180}$ See supra text accompanying note 117.

161 See Tinker v. Des Moines Indep. Community School Dist., 393 U.S. 503 (1969).

${ }^{162}$ FCC v. Pacifica Found., 438 U.S. 726 (1978) (upholding, without a majority opinion, FCC restriction of broadcasts of non-obscene but "indecent" speech).

103 Justice Brennan's Pacifica dissent lists a number of classics, including some pertinent Biblical passages. Id. at 771 (Brennan, J., dissenting). In Pico, ore of the banned books, Desmond Morris's The Naked Ape, contained no profane words but did have a few scattered sentences describing sexual acts in rather erudite language. See Pico, 457 U.S. at 903. 
school's legal title to the books or the library shelves, the school board's action cannot satisfy even the most cursory level of review. To demand that the board justify its actions is to decide the case against it; only by exempting school hibrary decisions from the first amendment altogether were the dissenters able to take the board's side. ${ }^{184}$

At first reading, our focused balancing approach appears to involve complex first amendment methodology, but it does reduce to a single question the issues in all of these public school cases. The question is simply whether the government has articulated a connection between a specific category of speech and disruption of the educational process. Where it can do so, as in Grayned, its regulations are valid; where it cannot, as in Tinker and Pico, the regulations must fall.

Two recent school employee relations cases, Perry Education Association v. Perry Local Educators' Association ${ }^{185}$ and Minnesota State Board for Community Colleges v. Knight, ${ }^{168}$ have also given the Court considerable difficulty. Both cases sharply divided the Court and bring into focus the inadequacy of public forum analysis.

Perry is the Court's most ambitious application of the public forum approach to date. ${ }^{167}$ In Perry, one union was the exclusive bargaining representative for teachers in the school district. A collective bargaining agreement granted this union the sole right of access to the interschool mail system and teacher mailboxes at the expense of a rival union that previously had equal access to the same system. The rival union sued to regain its position of equality.

Justice White, writing for a majority of five justices, began his opinion by elaborating on public forum doctrine. In the "quintessential" pubhic forum, he said, tiune, place, and manner regulations are allowed, but the government may not close the forum or engage in content regulation without a compelling state interest. ${ }^{168}$ Property that has been opened as a forum for public communication is

\footnotetext{
184 Id. at 909-10 (Rehnquist, J., dissenting); id. at 885 (Burger, C.J., dissenting); id. at 893 (Powell, J., dissenting); id. at 921 (O'Connor, J., dissenting).

168460 U.S. 37 (1983).

168104 S. Ct. 1058 (1984).

167 For a discussion of Perry, see Stone, supra noto 18, at 245-49.

${ }^{18 s}$ Perry, 460 U.S. at 45.
} 
treated as a public forum so long as it remains open, but the government has the option of closing it off entirely. ${ }^{169}$ Finally, public property "which is not by tradition or designation a forum for public communication"170 is subject to broad state control. Not only are time, place, and manner regulations proper, but the state may also "reserve the forum for its intended purposes, communicative or otherwise, as long as the regulation on speech is reasonable and not an effort to suppress expression merely because public officials oppose the speaker's view."171 Government decisions about these nonpublic forums apparently will receive relatively casual judicial scrutiny:

Implicit in the concept of the nonpublic forum is the right to make distinctions in access on the basis of subject matter and speaker identity .... The touchstone for evaluating these distinctions is whether they are reasonable in light of the purpose which the forum at issue serves . . . . [W] Wen government property is not dedicated to open communication the government may-without further justification-restrict use to those who participate in the forum's official business. ${ }^{172}$

Applying this test, Justice White saw little difficulty in uploolding the access restriction. As le saw the case, the collective bargaining agreement merely allowed the recognized union to use the faculty mailboxes for official documents in the performance of its official duties as collective bargaining agent. ${ }^{173}$ Hence, the only discrimination was between individuals performing official duties and other persons. As the dissent saw the case, however, the discrimination was essentially viewpoint based, since the recognized union was al-

168 Id. at $45-46$. The analysis is somewhat comphicated by the Court's view that a public forum "may be created for a limited purpose such as use by certain groups . . . or for the discussion of certain subjects." Id. at $46 \mathrm{n.7}$ (citations omitted). Thus, for "limited purpose non-quintessential public forums," subject matter restrictions are apparently permissible.

${ }^{170}$ Id. at 46.

171 Id. at 46 (citing United States Postal Serv. v. Council of Greenburgh Civic Ass'ns, 453 U.S. 114, 131 n.7 (1981)).

172 Id. at 49, 53 (emphasis added). Similarly, for equal protection purposes, because the dissenting union did not have a first amendment right of access to the mailboxes, the state need show only a rational basis for restrictions. Id. at 54 . To reach this conclusion, the Court liad to rewrite Mosley and Carey v. Brown, 447.U.S. 455 (1980), to involve rights of access. In reality, both cases used equal protection analysis in order to avoid the access question. See Carey, 447 U.S. at 459 n.2; Mosley, 408 U.S. at 96, 101-02.

${ }^{173}$ Perry, 460 U.S. at $53 \mathrm{n} .13$ (reading the collective bargaining agreement to give the official union access only as the teachers' representative, and not for "unlimited purposes"). 
lowed to use the mail system, but those opposing its views were not. ${ }^{174}$

The restriction at issue in Perry would fail the test proposed in this article on several counts. First, the decision to bar material from the school mailboxes was not made on the basis of a clear criterion. The members of the Supreme Court could not agree about which communications by the recognized union were permitted in the mailboxes. The record indicated as well that other organizations, generally not related to the schools at all, had also been allowed to use the system. ${ }^{175}$ As a result, it is impossible to say just what speech was proscribed and how that speech differed from the speech that was allowed. The government had not only failed to articulate a goal supporting the restriction, but it had failed even to articulate the restriction clearly enough to allow intelligent judicial analysis. ${ }^{176}$

The second problem with the Perry regulation relates to the goals that plausibly could underlie the restriction. One goal, which the Court euplemistically referred to as "labor peace,"177 was simply to prevent teachers from hearing the appeals of rival groups to which they might be attracted. As a general matter, silencing debate can hardly be considered a goal "unrelated to the suppression of free expression" as required by our test. ${ }^{178}$ Furtlermore, to the extent that the Court was correct that other methods of communication remained open, ${ }^{17 \theta}$ the restriction on use of mailboxes was poorly designed to serve the purpose of preventing the rival union from communicating with teachers. Thus, preserving labor peace by silencing the rival union could not be considered a reasonable basis for upholding the restriction.

An alternative explanation for the collective bargaining provision in Perry might be that the school district, with no interest of its own (other than that of winning concessions from the union), was

${ }^{174}$ Id. at 55-56, 62-66 (Brennan, J., dissenting).

${ }^{178}$ Local parochial schools, church groups, and civic groups had been allowed to use the system. See id. at $39 \mathrm{n} .2,47-48$. The record did not indicate whether any request to use the systein had ever heen denied. Id. at $39 \mathrm{n} .2$.

${ }^{178}$ In this respect, Perry resembles Schad v. Borough of Mt. Ephraim, 452 U.S. 61, 83-84 (1981) (Stevens, J., concurring).

177460 U.S. at 52.

${ }^{178}$ See supra text accompanying notes 107-11.

170 460 U.S. at 53. 
simply accommodating the official union's desire to repress its rival. ${ }^{180}$ But from the point of view of first amendment values, agreeing to censor a group only in order to appease its rivals is merely a vicarious interest in censorship and can stand on no better footing than would a direct interest.

The school district in Perry might have justified its restrictions with a number of other possible goals, as well. For example, the district could have argued that the restriction would help avoid overflow of the system, maintain security by denying physical access to unauthorized users, and prevent official communications from getting lost in a flood of "junk mail." These certainly are permissible goals under the first amendment and, being content neutral, would be judged under the time, place, and manner test. The problem is that the school system did not in fact distinguish between official and nonofficial communications: nonofficial communications of various kinds were allowed in the system. Indeed, the system of restrictions actually used by the school district would fail to pass as a time, place, and manner restriction not only because of its somewhat dubious reasonableness under the circumstances of the case, ${ }^{181}$ but also because school officials apparently retained unchecked discretion to allow or prohibit nonofficial communications (other than those of the rival union). ${ }^{182}$ Finally, and perhaps most plausibly, the collective bargaining provision may simply have been intended as a symbohic recognition of the unique status of the official union. It seems highly unlikely, however, that the state can make symbohic statements by suppressing the speech of others-surely that is carrying the concept of "symbohic speech" too far. One could perhaps go on indefinitely speculating about

\footnotetext{
180 This explanation is supported by the fact that only the two unions were parties to the case when it came before the Court. Apparently the official union, but not the school board, considered the appeal worth pursuing. See id. at 41; id. at $70 \mathrm{n.12}$ (Brennan, J., dissenting).

183 The court of appeals had concluded that the policy suffered from overinclusiveness and nnderinclusiveness and was unsupported by any factual evidence. See id. at 52-53 \& nn.12-13; id. at $67 \mathrm{n.9}$ (Brennan, J., dissenting). That access previously had been unlimited, without any ascertainable harm resulting, inust weigh heavily against the reasonableness of the school board's new, restrictive pohicy.

${ }^{382}$ Under time, place, and manner analysis, the Court must seek to limit administrative discretion. See Schad v. Borough of Mt. Ephraim, 452 U.S. 61, 84 (1981) (Stevens, J., concurring in the judgment) (zoning ordinance invalidly left municipal officials unbridled discretion to regulate speech). The focused balancing approach will require clear articulation of criteria for disparate treatment.
} 
reasons that might justify the provision, but that in itself shows why the provision would not survive our proposed test. The lawmaking authority had never articulated its reasons for the restriction, and no reasons are evident on the face of the law.

The focused balancing approach to situational regulations has the virtue of confronting the first amendment values at issue in Perry and weighing them against the government's possible justifications. The Perry opinion, on the other hand, simply brushed aside the first amendment problems in a geographical analysis based solely on the location of the speech.

While Perry qualifies as the Court's most ambitious apphication of pubhic forum analysis, Minnesota State Board for Community Colleges $v$. Knight ${ }^{\mathbf{1 8 3}}$ probably qualifies as the least thoughtful. The state law at issue in Knight authorized a college system's professional employees and academic administrators to engage in collective bargaining regarding employment contract terms, a form of associational regulation previously upheld by the Court. ${ }^{184}$ More important, the statute required "pubhic employers"-academic administrators in this case-to "meet and confer" with professional employees on pohicy questions relating to college pohcy and governance, but outside the scope of contract bargaming negotiations. Because the college's professional employees had formed a bargaining unit and selected an exclusive union representative, the statute required college administrators to limit formal discussion of these general policy issues to representatives selected by the union. The Court correctly phrased the issue as "whether this restriction on participation in the nonmandatory-subject exchange process violates the constitutional rights of professional employees witlim the bargaining unit who are not members of the exclusive representative and who may disagree with its views."18s Amazingly, the majority opinion upheld the law with virtually no analysis of the ways in which this restriction on the exchange of information among professional employees and administrators of a college might imphicate first amendment values.

Justice O'Connor, writing for the majority, apparently assumed that the regulation did not significantly restrict the ability of non-

\footnotetext{
$18 s 104$ S. Ct. 1058 (1984).

14 See Abood v. Detroit Bd. of Educ., 431 U.S. 209 (1977).

$183104 \mathrm{~S}$. Ct. at 1060.
} 
union employees to communicate their views on policy issues to college administrators. This assumption seems to run contrary to the findings of the trial court, as noted by the dissenters. It also disregards the fact that union representatives who met with academic administrators im "meet and confer" pohicy discussions had invoked their right to silence other people who attempted to speak during these sessions. ${ }^{188}$ The majority believed that the nonunion employees were asking the Court to estabhish a constitutionallybased principle of open meetings, which would require the government to invite all members of the public to air their views on policy issues. The Court responded that "[t]o recognize a constitutional right to participate directly in government policymaking would work a revolution in existing government practices."187 This conclusion, however, has hittle to do with the issue as the Court originally framed it. The majority's rephrasing of the constitutional principle at issue disregards the testimony of school administrators in this case who indicated they would have been willing to consider the views of nonunion teachers in their "meet and confer" sessions, but were prohibited from doing so by the statute. ${ }^{188}$

The trial court findings in Knight were less than a model of clarity: ${ }^{189}$ it may well be that the statute really had little impact on the ability of academic professionals to excliange views on policy matters with school administrators. ${ }^{190}$ Perhaps the decision could have been defended in an opmion that openly considered the first amendment values at stake. For instance, the majority may have believed that the statute enhanced the ability of the government to receive in a structured way the views of the majority of its employees, while allowing other employees to commumicate their views through other channels.

18s See id. at 1076-77 (Stevens, J., dissenting).

${ }_{187}$ Id. at 1066; see also Bi-Metallic Inv. Co. v. State Bd. of Equalization, 239 U.S. 441 (1915) (rejecting a due process challenge to a general increase in tax evaluations of property, promulgated without an opportunity for taxpayers to be heard or to appear hefore the board); cf. City of Madison Joint School Dist. No. 8 v. Wisconsin Employment Relations Comm'n, 429 U.S. 167 (1976) (sustaining a first amendment challenge to restrictions on teachers' access to a school board meeting open to the public, while recognizing the right of public bodies to hold nonpublic sessions to transact business).

${ }^{188} \mathrm{Knight,} 104 \mathrm{~S}$. Ct. at 1081 (Stevens, J., dissentimg).

${ }^{189}$ Compare id. at 1069 n.12 with id. at 1078 (Stevens, J., dissenting) (differing interpretations of district court's findings).

${ }^{100}$ See id. at $1062 \mathrm{n.4}$ (majority disparaging Justice Stevens' remarks in dissent as to the impairment of free speech caused by the statute). 
Under the focused balancing approach set forth in this article, it would be very difficult to uphold the statutory monopoly for union speakers if it significantly impaired the speech of others. As in Perry, the government could articulate no goal advanced by this statute other than a vague interest in labor relations. That goal inay support restricted access to contract negotiations, but it does not indicate why speech by union representatives on issues outside the scope of inandatory bargaining is to be preferred over speech by other persons. As Justice Stevens pointed out in dissent, a governmental interest im restricting speech on pohicy issues seems inconsistent with first ainendment values. ${ }^{191}$ The statutory system in Knight denied individuals the ability to communicate with their government merely because their views differed from those of their official spokesperson for employment purposes. This prohibition underınined the hibertarian values of the first ainendment, and by restricting the exchange of information over policy decisions to a discussion of views acceptable to a governmentally recognized entity (the union), the law undercut the first amendment's marketplace value as well. If the government wishes to have a "Robert's Rules of Order" type of regulation that allows nonunion speakers only a limited ability to participate in these discussions, or a separate time for communication, the government may be able to articulate a viewpoint-neutral interest in structuring the exchange of information witl its einployees regarding pohicy issues. The regulation at issue, however, was not tailored to achieving an efficient consideration of the views of professional employees; it was a legislatively mandated determination of whose views were wortliy of consideration by government decisionmakers.

Even if a focused balancing approach would not have led the Court to a different conclusion in Knight, it would at least have exposed the difficulty of reconciling the regulation with first amendment values. Justice O'Connor's use of pubhic forum analysis allowed the Court to approve the statute with hittle consideration of first amendment values. As Justice O'Connor in other cases has deinonstrated some sensitivity to the need for judicial protection of the free flow of information in society, ${ }^{102}$ we assune that her opin-

${ }^{101}$ Id. at 1074-75 (Stevens, J., dissenting).

${ }^{102}$ See Minneapolis Star \& Tribune Co. v. Minnesota Comm'r of Revenue, 460 U.S. 575 
ion reflects a position taken by a majority of the Justices that public forum analysis is all that is necessary to explain situational content regulation cases. In Knight, Justice O'Connor's consideration of first amendment issues consisted principally of the decision that the public forum cases are not relevant to the claim of the nonunion teachers. The Court had held in City of Madison Joint School District v. Wisconsin Employment Relations Commission ${ }^{193}$ that nonunion teachers could not be barred from expressing their views regarding policy issues in a public meeting. The Court found that the claim of the college teachers in Knight was "wholly unhike" the claim in Madison Joint School District because that decision only "upheld a claim of access to a public forum, applying standard public-forum First Amendment analysis."194 Indeed the Court in Knight found that, because the goverument had always limited these "meet and confer" sessions to interchanges with representatives of the official union, it need not even consider the relevance of nonpublic forum cases such as Perry. ${ }^{105}$

The only other treatment of first amendment values in the Knight opinion consisted of the following three conclusions, each supported by virtually no analysis. First, "[f]aculty involvement in academic governance has much to recommend it as a matter of academic policy, but it finds no basis in the Constitution."198 Second, "[t]he state has in no way restrained appellees' freedom to speak on any education-related issue or their freedom to associate or not to associate with whom they please, including the exclusive representative. Nor has the state attempted to suppress any ideas." 197 Third, "[a] person's right to speak is not infringed when government simply ignores that person while listening to otliers." ${ }^{188} \mathrm{Re}-$

(1983) (O'Connor, J.) (special tax on ink and paper used in newspapers held unconstitutional); Globe Newspaper Co. v. Superior Court, 457 U.S. 596, 611 (1982) (O'Connor, J., concurring) (law that required clearing a courtroom of press and public during testimony of a minor allegedly a victim of a sex crime held unconstitutional). But cf. Board of Educ. v. Pico, 457 U.S. 853, 921 (1982) (O'Connor, J., dissenting) (arguing that school board may decide which books to remove from school hbrary as long as there is no interference with the students' right to read and discuss the material).

193429 U.S. 167 (1976).

184 Knight, 104 S. Ct. at 1064.

${ }^{295}$ Id. at 1065 ("nonpublic forum cases are largely irrelevant").

108 Id. at 1068 .

197 Id.

198 Id. 
sponding to the nonunion employees' equal protection argument, the Court summarily concluded that the selection of certain speakers and viewpoints for consideration by the government was valid because "[t]he state has a legitimate interest in ensuring that its public employers hear one, and only one, voice presenting the majority view of its professional employees on employment-related policy questions."189

A distinction can be made between restrictions on speakers in public school board meetings and the "meet and confer" sessions in terms of public forum analysis, but it is one devoid of substance. As Justice Marshall, concurring in the judgment, ${ }^{200}$ and Justices Brennan, Stevens, and Powell, in dissent, ${ }^{201}$ demonstrated, honest disagreement may exist over whether restrictions on the ability to communicate with the government violate first amendment values by denying some people a meaningful opportunity to express their views in the democratic process. ${ }^{202}$ The marketplace value of the first amendment does appear to be undercut by a statute that prohibits a pubhic employer from histening to meritorious speech because the views expressed are not approved by a publicly recognized (although nongovernmental) entity. We can only hope that the majority, hike the concurring and dissenting Justices, considered the first amendment values at stake in Knight and merely used formal pubhic forum analysis as a way of bolstering their conclusion that judges were not empowered by the first amendment to guarantee access to government decisionmakers. It would be a tragedy if the Justices in the majority actually believed that categorization of the context of the speech as a public, nonpublic, or other type of forum resolved the first amendment issues in Knight.

\footnotetext{
100 Id. at 1069 .

200 Id. at 1070 (Marshall, J., concurring).

${ }^{201}$ Id. at 1072 (Brennan, J., dissenting); id. at 1074 (Stevens, J., joined by Powell, J., dissenting).

${ }^{202}$ Compare id. at 1070-72 (Marshall, J., concurring) ("the constitutional authority of a government decisionmaker to choose the persons to whom he will and will not listen prior to making a decision varies with the nature of the decision at issue and the institutional environment in which it must be made") with id. at 1074-78 (Stevens, J., dissenting) ("the First Amendment does guarantee an open marketplace for ideas where divergent points of view can freely coinpete for the attention of those in power and of those to whom the powerful must account"). But see id. at 1068 n.10 (O'Connor, J.) (rejecting discussion of associational rights and the right to "a meaningful opportunity to express one's views" as being "beside the point").
} 


\section{Conclusion}

This article has attempted to demonstrate that the current public forum debate endangers judicial protection of first amendment values. We have seen that situational regulations cannot be adequately analyzed by simply classifying types of forums. Although they are useful for other problems, the censorship and the time, place, and manner models of first amendment adjudication have been equally unsuccessful in analyzing situational restraints. ${ }^{203}$ Situational regulations, however, may be the most significant first amendment area the Court will face in the near future. A long history of attempts at censorship notwithstanding, it is unlikely that the government will undertake any novel efforts to excise any particular message from society. True time, place, and manner problems have neither posed significant difficulties for the Court nor threatened first amendment values. But government attempts to regulate access to certain channels of communication on the basis of content are hkely to recur with greater frequency in the years ahead. At present, the Court lacks a straightforward analysis of this difficult problem. The Court's current method of analysis-the public forum doctrine-has led to confused opinions and a disregard for first amendment values. ${ }^{204}$

This article's proposed focused balancing test is a judicially manageable response to situational regulations. Additionally, it will benefit other actors in the governance system by openly disclosing the basis of the Court's rulings. The test allows independent judicial review of whether the regulated speech (1) has an impact on its physical or social environment different from other types of speech and (2) interferes with a legitimate societal interest unrelated to censorship or propaganda goals. The test protects first amendment values by eliminating the possibility of overt or subtle forms of censorship, but at the same time it allows society to achieve legitimate goals unrelated to the suppression of disfavored ideas. Unhke ad hoc balancing, focused balancing requires the government to prove that the lawmakers articulated a goal at the time they enacted the statute, thus ensuring that the law cannot be used as a pretext for the suppression of ideas. It also requires the

203 See supra text accompanying notes 52-53, 70-81.

204 See supra text accompanying notes 16-28. 
government to demonstrate that the incidental burden on speech is clearly outweighed by society's need to avoid the speech's adverse impact on its environment. ${ }^{205}$

The easiest cases to analyze involve government claims that the regulated speech has a particular impact on its physical environment. A common example is the claim that the speech makes it impossible for others to speak. Here, the government seeks only to employ a "Robert's Rules of Order" approach to the regulation of speech. ${ }^{208}$ The test explains why a student may be punished for discussing the World Series in history class, ${ }^{207}$ or why the lawyer who insists on asking irrelevant questions can be held in contempt of court, ${ }^{208}$ without opening the door to widespread governmental controls of the content of messages. The government must demonstrate that the regulated speech has a unique impact on the classroom or courtroom that interferes with important societal interests. In the balancing phase of the test, the government must show that the articulated interest serves as the actual basis for the governmental action. This interest must have independent significance apart from the regulation of ideas and must confer a societal benefit clearly outweighing the burden on speech. The test not only solves the theoretical problem of why we can punish yelling "Fire!" in a crowded theater, but also makes understandable some of the Court's physical impact decisions. Even in these relatively easy cases, our approach will help to safeguard first amendment values and clarify first amendment theory.

The most difficult problems arise when the government asserts that speech must be separately regulated because its content has a detrimental (but not directly physical) impact on its environment or on the medium of communication. Here, we find some of the

\footnotetext{
${ }^{203}$ See supra text accompanying notes 105-18.

${ }^{208}$ See Kalven, supra note 14, at 23-25, 27; see also Consolidated Edison Co. v. Public Serv. Comm'n, 447 U.S. 530, 546 (1980) (Stevens, J., concurring) ("some forms of orderly regulation actually promote freedom more than would a state of total anarcly").

${ }^{207}$ See Consolidated Edison Co. v. Public Serv. Comm'n, 447 U.S. 530, 544-45 (1980).

${ }^{208}$ Justice Stevens has pointed out tlie extent to which lawyers' speecb is subject to judicial control. See id. at 545-46. Evidence law consists almost entirely of restrictions on the content of speech. Often, these rules involve highly paternalistic assumptions about the audience, i.e., the jury. See Farber, Commercial Speech and First Amendment Theory, 74 Nw. U.L. Rev. 372, 402 (1979). Yet it would be absurd to see any serious first amendment problem in the jury trial context. There is even less of a problem when the court is simply attempting to prevent a lawyer from wasting its time.
} 
Court's most confusing opinions, such as Perry Education Association v. Perry Local Educators' Association ${ }^{209}$ or Minnesota State Board for Community Colleges v. Knight, ${ }^{210}$ as well as cases in which the Court has been unable to produce a majority opinion at all, such as Board of Education v. Pico. ${ }^{211}$ Other situational regulation cases of this genre are FCC $v$. Pacifica Foundation, ${ }^{212}$ which involved a ban on an "indecent" afternoon radio broadcast that the Court described as a "pig in the parlor" ";13 Young v. American Mini Theatres, Inc., ${ }^{214}$ which involved a plan to disperse adult entertainment throughout a city by zoning; and Lehman v. City of Shaker Heights, ${ }^{218}$ in which a city allowed commercial but not political ads on its buses. Use of pubhic forum analysis, or attempts to analogize these problems to content proscription cases, can only produce confusion and obscure the first amendment values at issue in these cases.

The model of adjudication proposed in this article allows both an explanation and critique of these decisions. Perry is an incorrect decision because the Court failed to demand a noncensorial justification, instead merely categorizing the medium of communication as a nonpublic forum. ${ }^{216}$ The Court's decisions in Pacifica and Mini Theatres, however, are both justifiable and understandable under our model. In each case, the Court beheved that "adult" communications had a special impact on a particular environment-in Pacifica because of the unusual intrusiveness of broadcasting directly into the home, ${ }^{217}$ and in Mini Theatres because of the effect on neighborhoods of concentrations of adult entertain-

\footnotetext{
200460 U.S. 37 (1983).

210104 S. Ct. 1058 (1984).

211457 U.S. 853 (1982).

212438 U.S. 726 (1978).

${ }^{213}$ Id. at 750 (quoting Village of Euclid v. Ambler Realty Co., 272 U.S. 365, 388 (1926) (Sutherland, J.)).

214427 U.S. 50 (1976).

215418 U.S. 298 (1974). In this $5-4$ decision, the Justices held that a city that operates a public rapid transit system may restrict sale of advertising space in its vehicles to commercial and public service advertising and may refuse to accept any public issue advertising or political advertising on behalf of candidates for public office.

${ }^{218}$ See supra text accoinpanying notes 167-82.

${ }_{217}$ In Pacifica, even Justice Brennan conceded that a restraint on offensive language in broadcasting specifically directed at children might be justified. FCC v. Pacifica Found., 438 U.S. 726, 768 n.3 (1978) (Brennan, J., dissenting). For an application of an earlier form of our approach to Pacifica, see Farber, supra note 8, at 754-58.
} 
ment businesses. ${ }^{218}$ In both cases, the focused balancing test advocated in this article (and adumbrated in Justice Stevens' opinions) ${ }^{219}$ would have forthrightly addressed the first amendment values at stake while allowing society to achieve legitimate interests. Even Lehman, perhaps the most problematic of these cases, may make sense if a distinction between commercial and political speech on public transportation is indeed reasonably related to the asserted governmental interests: protection of captive audiences and allocation of advertising space in a manner that avoids the risk of distorting the pohtical process. ${ }^{220}$

Our approach will not solve all the cases or settle all first amendment issues. We offer the model not as a himus test for the validity of governmental regulations but as an alternative to the simphistic public forum analysis that has dominated recent decisions of the Court. Public forum analysis fails to illuminate the true problem at hand and the first amendment values at stake. For example, it is less than obvious whether intentional infliction of emotional distress, which might normally be a tort, is protected speech when it is accomphshed by marching in Nazi uniforms through a neighborhood populated by Holocaust survivors. ${ }^{221}$ The one point

\footnotetext{
${ }_{11}$ For useful discussions of Mini Theatres, see Farber, supra note 8, at 732-33, 750 (the "paradigm" for "equal protection analysis of content-based classification scbemes"); L. Tribe, supra note $30, \S \S 12-18$ to $12-19$.

210 Virtually all of Justice Stevens' opinions on first amendment issues are consistent with our analysis. See Bolger v. Youngs Drug Prods. Corp., 103 S. Ct. 2875, 2888 (1983) (Stevens, J., concurring); Widmar v. Vincent, 454 U.S. 263, 277 (1981) (Stevens, J., concurring); FCC v. Pacifica Found., 438 U.S. 726 (1978) (Stevens, J.) (plurality opinion); Young v. American Mini Theatres, Inc., 427 U.S. 50 (1976) (Stevens, J.) (plurality opinion).

Justice Stevens recently wrote for six members of the court in upholding a city prohibition of the posting of signs on public property. Members of the City Council of Los Angeles v. Texpayers for Vincent, $104 \mathrm{~S}$. Ct. 2118 (1984). Justice Stevens noted that streetlight posts, upon which a political candidate wished to place his election messages, were not a traditional public forum. He did not, however, rely on this observation as the basis for upholding the ordinance. Instead, he noted that the government had a significant interest in eliminating esthetically unpleasing property uses, that the restriction was content neutral, and that there were adequate alternative means of communication. Even though prior decisions required him to pay lip service to the public forum distinction, Justice Stevens attempted to analyze the city's goals and the impact of the law on first amendment values in a manner consistent with the focused balancing test.

${ }^{220}$ See Farber, supra note 8, at 761-62 (explaining Lehman).

211 See Collin v. Sinith, 578 F.2d 1197, 1205-06 \& n.17 (7th Cir.), cert. demed, 439 U.S. 916 (1978); see also Village of Skokie v. National Socialist Party of America, 69 Ill. 2d 605, 373 N.E.2d 21 (1978) (use of swastika by National Socialist Party member is protected speech); see generally Bollinger, supra note 83 (free speech includes willingness to tolerate
} 
that does seem clear is that labeling where the Nazis wish to march as a "public" or "nonpublic" forum does nothing to advance the analysis. Open analysis of the impact of speech on the environment and an honest balancing of the values at stake is the only way to deal with such an issue. Unless the Supreme Court transcends its geographical approach to the first amendment and abandons formal public forum analysis, it will continue to hand down decisions that fail to analyze thoughtfully the nature and role of first amendment principles in our society.

offensive forms of expression); Farber, Civilizing Public Discourse: An Essay on Professor Bickel, Justice Harlan, and The Enduring Significance of Cohen v. California, 1980 Duke L.J. 283, 295-302 (1980) (offensive forms of expression are an important part of speaker's inessage and should be protected). 